\title{
Raptors of the Hanford Site and Nearby Areas of Southcentral Washington
}

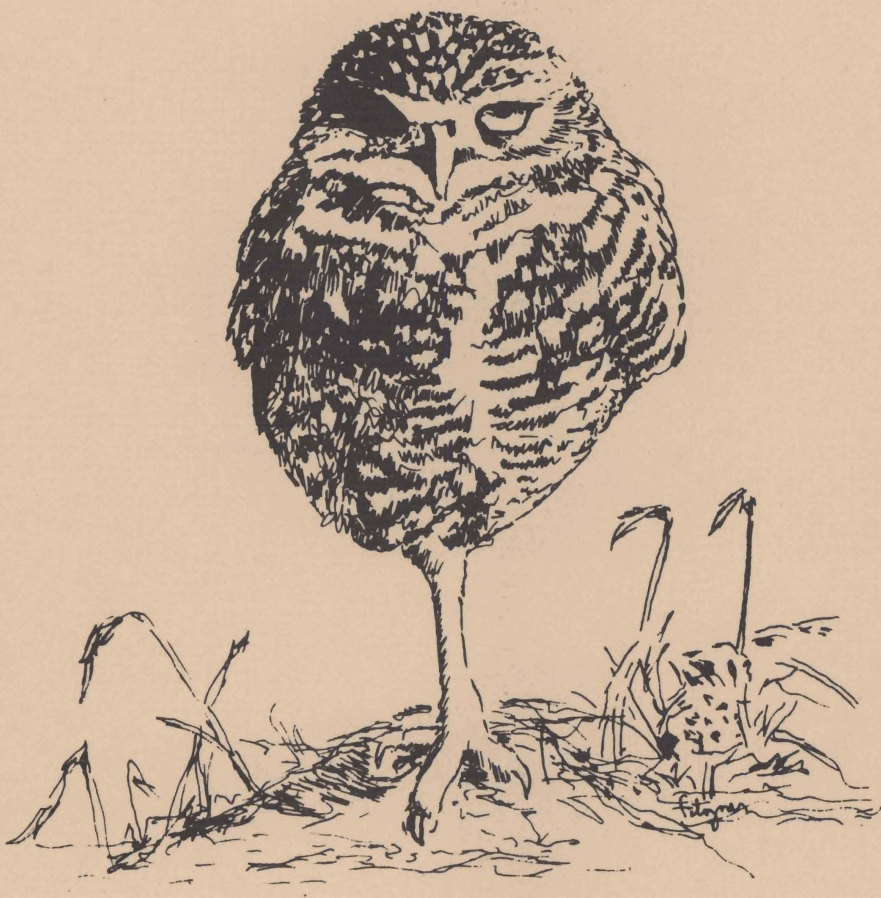

Prepared for the Department of Energy and Rockwell Hanford Operations under Contract DE-AC06-76RLO 1830

Pacific Northwest Laboratory Operated for the U.S. Department of Energy by Battelle Memorial Institute 


\section{NOTICE}

This report was prepared as an account of work sponsored by the United States Government. Neither the United States nor the Department of Energy, nor any of their employees, nor any of their contractors, subcontractors, or their employees, makes any warranty, express or implied, or assumes any legal liability or responsibility for the accuracy, completeness or usefulness of any information, apparatus, product or process disciosed, or represents that its use would not infringe privately owned rights.

The views, opinions and conclusions contained in this report are those of the contractor and do not necessarily represent those of the United States Government or the United States Department of Energy.

\section{PACIFIC NORTHWEST LABORATORY}

operated by

BATTELLE

for the

UNITED STATES DEPARTMENT OF ENERGY

Under Contract DE-AC06-76RLO 1830

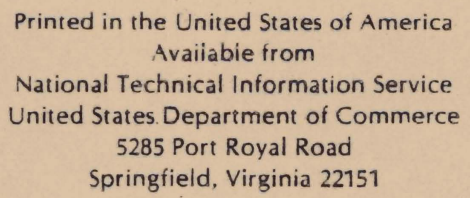

Price: Printed Copy $\$$

*; Microfiche $\$ 3.00$

NTIS

*Pages Selling Price

$\begin{array}{lr}001-025 & \$ 4.00 \\ 026-050 & \$ 4.50 \\ 051-075 & \$ 5.25 \\ 076-100 & \$ 6.00 \\ 101-125 & \$ 6.50 \\ 126-150 & \$ 7.25 \\ 151-175 & \$ 8.00 \\ 176-200 & \$ 9.00 \\ 201-225 & \$ 9.25 \\ 226-250 & \$ 9.50 \\ 251-275 & \$ 10.75 \\ 276-300 & \$ 11.00\end{array}$




\section{1}

RAPTORS OF THE HANFORD SITE AND NEARBY

AREAS OF SOUTHCENTRAL WASHINGTON
R. E. Fitzner
W. H. Rickard
L. L. Cadwel1
L. E. Rogers

May 1981

Prepared for the Department of Energy and Rockwell Hanford Operations under Contract DE-AC06-76RLO 1830

Pacific Northwest Laboratory

Richland, Washington 99352 
INTRODUCTION

STUDY AREA

METHODS

GENERAL CONSIDERATIONS

TURKEY VULTURE . GOSHAWK

COOPER'S HAWK

SHARP-SHINNED HAWK

MARSH HAWK

AMERICAN ROUGH-LEGGED HAWK

FERRUGINOUS HAWK

RED-TAILED HAWK

SWAINSON'S HAWK

AMERICAN KESTREL

PIGEON HAWK

PRAIRIE FALCON

OSPREY

GOLDEN EAGLE

BALD EAGLE

GREAT HORNED OWL

LONG-EARED OWL .

SHORT-EARED OWL

BARN OWL

FLAMMULATED OWL

SAW-WHET OWL

SNOWY OWL .

BURROWING OWL

SCREECH OWL

POPULATION AND PRODUCTIVITY POPULATION DATA PRODUCTIVITY

SEASONAL USE OF THE HANFORD SITE BY RAPTORS.$\quad \cdot \quad \cdot \quad \cdot \quad \cdot \quad \cdot 36$

THE BREEDING POPULATION •

THE NON-BREEDING POPULATION $\cdot \cdot \cdot \cdot \cdot \cdot \cdot \cdot 36$

THE BREEDING CHRONOLOGY OF RAPTORS ON THE HANFORD SITE : $\bullet \quad \cdot 37$

FOOD OF THE STRIGIFORMES AND FALCONIFORMES $\quad \cdot \quad \cdot \quad \cdot \quad \cdot \quad \cdot \quad \cdot 39$

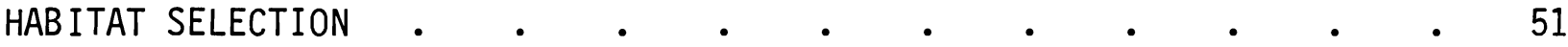

USE OF RAPTOR PELLETS IN RADIOECOLOGICAL SURVEILLANCE.$\quad \cdot \quad \cdot \quad \cdot 55$

ACKNOWLEDGMENTS

REFERENCES 


\section{FIGURES}

1 The Hanford Site

Plant Communities of the Hanford Site

General study area where raptor sightings have been recorded

Locations of Nesting and Non-nesting Pairs and Single Owls - 1975

Locations of Nesting and Non-nesting Pairs and Single Owls - 1976

Locations of Nesting and Non-nesting Pairs and Single Owls - 1977

Locations of Nesting and Non-nesting Paris and Single Owls - 1978

8 Locations of Nesting and Non-nesting Pairs and Single

9 Locations of Nesting and Non-nesting Pairs and Single Red-tailed and Swainson's Hawks - 1976

10 Locations of Nesting and Non-nesting Pairs and Single Red-tailed and Swainson's Hawks - 1977

11 Locations of Nesting and Non-nesting Pairs and Single Red-tailed and Swainson's Hawks - 1978 Nesting Sites used by Marsh Hawks, Prairie Falcons, and American Kestrels from 1975-1978 
1 Taxonomic Listing of the Birds of Prey of the Hanford Site . $\quad 8$

2 Productivity of Owls 1975-1978 .

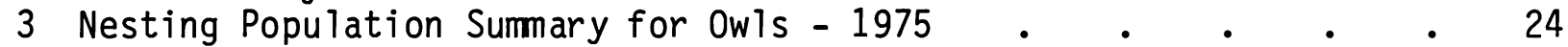

4 Nesting Population Summary for Owls - 1976 • $\quad$ • $\quad$ • $\quad$ • $\quad$ e 24

5 Nesting Population Sumary for Owls - 1977 • $\quad$ • $\quad$ • $\quad$ • $\quad$ • 25

6 Nesting Population Summary for Owls - 1978 . $\quad$ • . . . . $\quad$ e 25

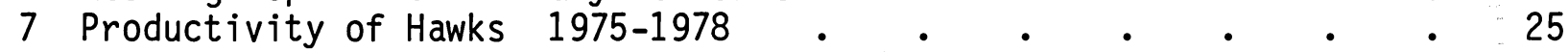

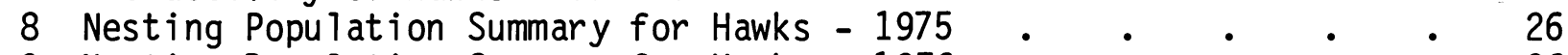

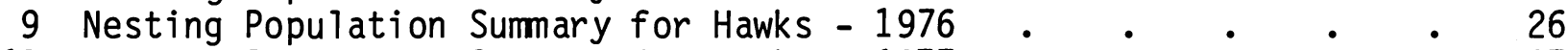

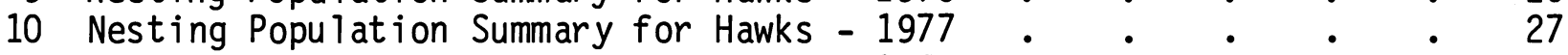

11 Nesting Population Sumary for Hawks - 1978 . $\quad$ • $\quad$ • $\quad$ • $\quad$ • 27

12 Number of Individual Adult Raptors Living on the Hanford

13 Body Weights of Raptors Nesting on the Hanford Site

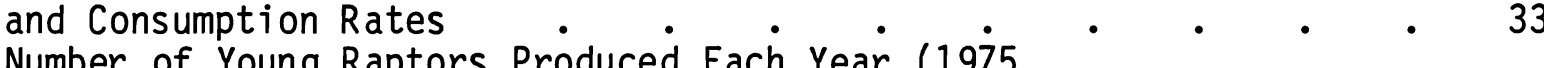

14 Number of Young Raptors Produced Each Year (1975

15 Productivity of Raptorial Birds on the Hanford Site--1975

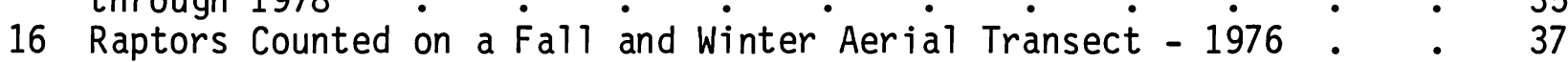

17 Reproductive Chronology of Nesting Owls on the Hanford Site . . 38

18 Reproductive Chronology of Nesting Hawks on the Hanford Site . . 38

19 Food of Great Horned Owls in the Shrub-steppe of

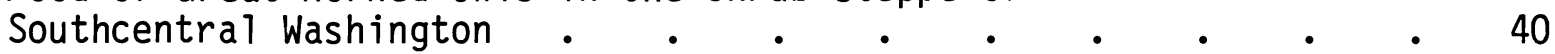

20 Food of Long-eared Owls in the Shrub-steppe of
Southcentral Washington

21 Food of Burrowing Owls in the Shrub-steppe of

22 Food of Barn Owls Nesting in the Shrub-steppe of

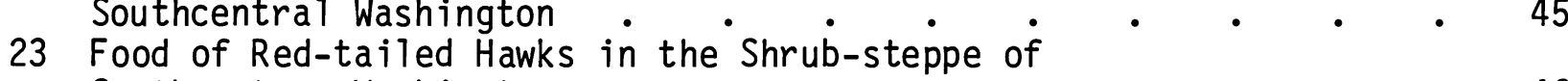

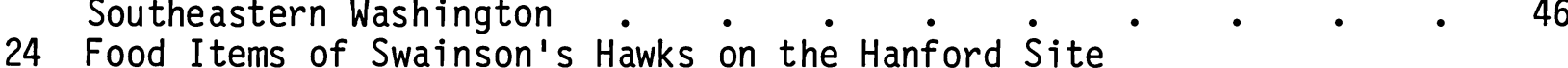

(Prey Fed to Young Hawks by Parent Birds) - 1973-76 . $\quad . \quad$. 47

25 Food Items of Swainson's Hawks on the Hanford Site

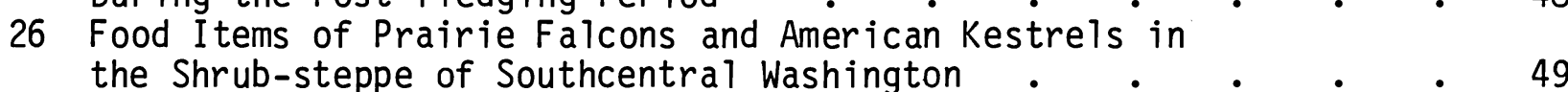

27 Biomass of Swainson's Hawks Produced on the Hanford Site $\quad$. $\quad 50$

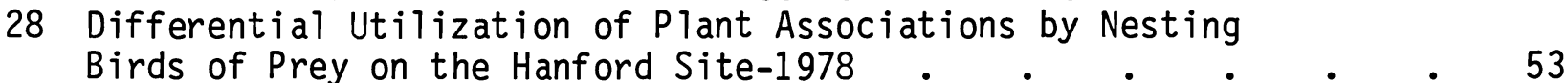

29 Differential Utilization of Nesting Structure by Birds of ${ }^{2}$ Prey on the Hanford Site--1978 .

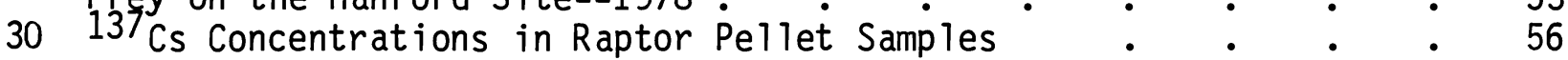

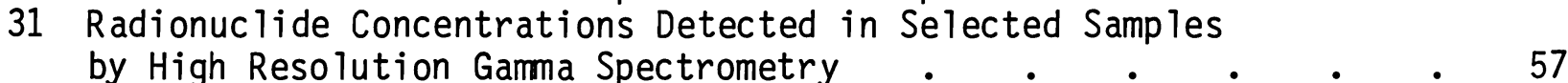

32 Radionuclide Concentrations in Owl Pellets.$\quad$. $\quad . \quad$. $\quad$. 58 


\section{INTRODUCTION}

The Hanford Site was established by the U.S. Atomic Energy Commission as a defense materials production facility in 1943. The processing, disposal and storage of radioactive waste has continued since the $1940 \mathrm{~s}$, although all but one of the defense materials production reactors were closed in the 1950s. The site's 570 square miles have been closed to unauthorized human trespass since its inception. This closure benefited many wildlife species (Hanson and Eberhardt 1970, Hedlund 1975). Today, the Hanford site harbors a 1 arge and diverse population of birds of prey.

In order to determine the nesting species present and to gain some understanding of their relative abundance, Pacific Northwest Laboratory (operated by Battelle Memorial Institute for the U.S. Department of Energy) contracted Dr. Richard R. 0lendorff to conduct field work in 1973 on the birds of prey residing on the Hanford Site (0lendorff 1973a). The intent of his efforts was to survey the nesting raptor population and to evaluate their potential for future research. His studies laid the groundwork for several research projects dealing with raptors.

A long-term study concerning the breeding ecology and behavior of the Swainson's hawk was initiated in April of 1973, concurrent with 01endorff's raptor population surveys. The Swainson's hawk study continues today and the data through 1977 were used in the publication of a Ph.D. thes is (Fitzner 1978).

This report is concerned with the birds of prey which use the Hanford Site not only during the nesting season but throughout the year. An ecological treatment of five nesting owls (great horned, long-eared, short-eared, barn and burrowing) and five nesting hawks (marsh hawk, red-tailed hawk, Swainson's hawk, prairie falcon and American kestrel) is provided and supportive information on non-nesting species is presented. Factors which control raptor densities and population dynamics throughout all seasons of the year are discussed. Information is also provided for raptors from other areas of southcentral washington in order to yield a comprehensive picture of how the Hanford Site fits in with regional bird of prey populations. The following were the objectives of this study: 1) To determine the numbers of birds of prey nesting on the Hanford Site, 2) To document the reproductive chronology of each nesting raptor species, 3) To provide analyses of food habits of birds of prey on the Hanford Site coupled with prey abundance data, 4) To determine the productivity of the dominant large birds of prey on the Hanford Site, 5) To determine the distribution and 1 and use patterns of a 11 raptors on the Hanford Site, 6) To determine the kinds and relative abun- dance of non-nesting raptors on the Hanford Site and adjacent areas of southcentral Washington 7) To document present land use practices on the Hanford Site and their effects on raptors, 8) To document radionuclide levels in birds of prey on the Hanford Site, and 9) To determine the role of birds of prey in radioecological monitoring. 


\section{STUDY AREA}

Studies were conducted on the U.S. Department of Energy's Hanford Site from 1973 through 1978.

The Hanford Site lies at the southeastern end of the lower Columbia Basin and consists of approximately $1476 \mathrm{~km}^{2}(147,715 \mathrm{ha})$ in Benton and Franklin Counties (Figure 1). It is bordered by the Columbia River on the east and the Yakima River to the south. This site was established in 1943 as a national security area and was closed to agriculture, grazing and unofficial travel. In 1968, the Atomic Energy Commission (now DOE) set aside a portion ( $311 \mathrm{~km}^{2}$ ) of the site south of Highway 240 as an ecological study area called the Arid Lands Ecology (ALE) Reserve. During the early 1970's, 12,950 ha north of the Columbia River were leased to the U.S. Fish and Wildlife Service to be known as the Saddle Mountain Refuge. The Washington Department of Game was also given a lease on 21,853 ha to be used for outdoor recreation. In 1977, the Hanford Site was set aside as a National Environmental Research Park by the U.S. Energy Research and Development Administration (now DOE).

The most prominent topographic feature of the site is Rattlesnake Mountain, on the western boundary, which rises to $1100 \mathrm{~m}$ above mean sea level. For $5 \mathrm{~km}$, the uniform crest of the mountain is $1100 \mathrm{~m} \mathrm{high,} \mathrm{dropping} \mathrm{on} \mathrm{its}$ southeastern end to $125 \mathrm{~m}$ at the water gap of the Yakima River. Northwest of this large crest, a jumbled topography, much less than $1000 \mathrm{~m}$ in elevation, merges with the northwest continuation of the Rattlesnake Hills (Brown 1968). The north slope of the mountain drops steeply (about 25 degrees) onto the ALE Reserve to about $650 \mathrm{~m}$ elevation, then eases to 7 degrees down to about $350 \mathrm{~m}$, and finally slopes more gently to Cold Creek Valley at $150 \mathrm{~m}$. North of Cold Creek Valley ( 150 to $200 \mathrm{~m}$ ), the land surface rolls gently while rising to about $225 \mathrm{~m}$ on the crest of a broad ridge (Rickard et al. 1974). The Saddle Mountains rise in elevation to $925 \mathrm{~m}$ to the north. The Rattlesnake Hills and Saddle Mountains are separated by the Columbia River and an expanse of monotonous topography interrupted by an alignment of basaltic ridges (Gable Mountain and Gable Butte) which run east-west near the middle section of the Hanford Site. A series of steep-walled cliffs along the north and east shores of the Columbia, upstream from the old Hanford townsite, form another striking interruption to the site. Unstabilized sand dunes occur as scattered islands of various sizes ranging from 1 ha to several thousand ha. The most extensive dune complex lies along the east bank of the Columbia River opposite Ringold.

The climate of the Hanford Site is strongly influenced by the Cascade Mountain Range to the west, which forms a barrier to moisture-1aden winter storms moving eastward from the Pacific 0cean. The resultant moisturedepleted air is warmed and further dried as it descends the eastern slopes of the Cascade Mountains (Thorp and Hinds 1977).

Annual precipitation at the Hanford Meteorological Station averages $16.5 \mathrm{~cm}$, ranging from 7 to $30 \mathrm{~cm}$ over the past 30 years (Stone et a1. 1972). On the average, $60 \%$ of the precipitation occurs between October and February. 


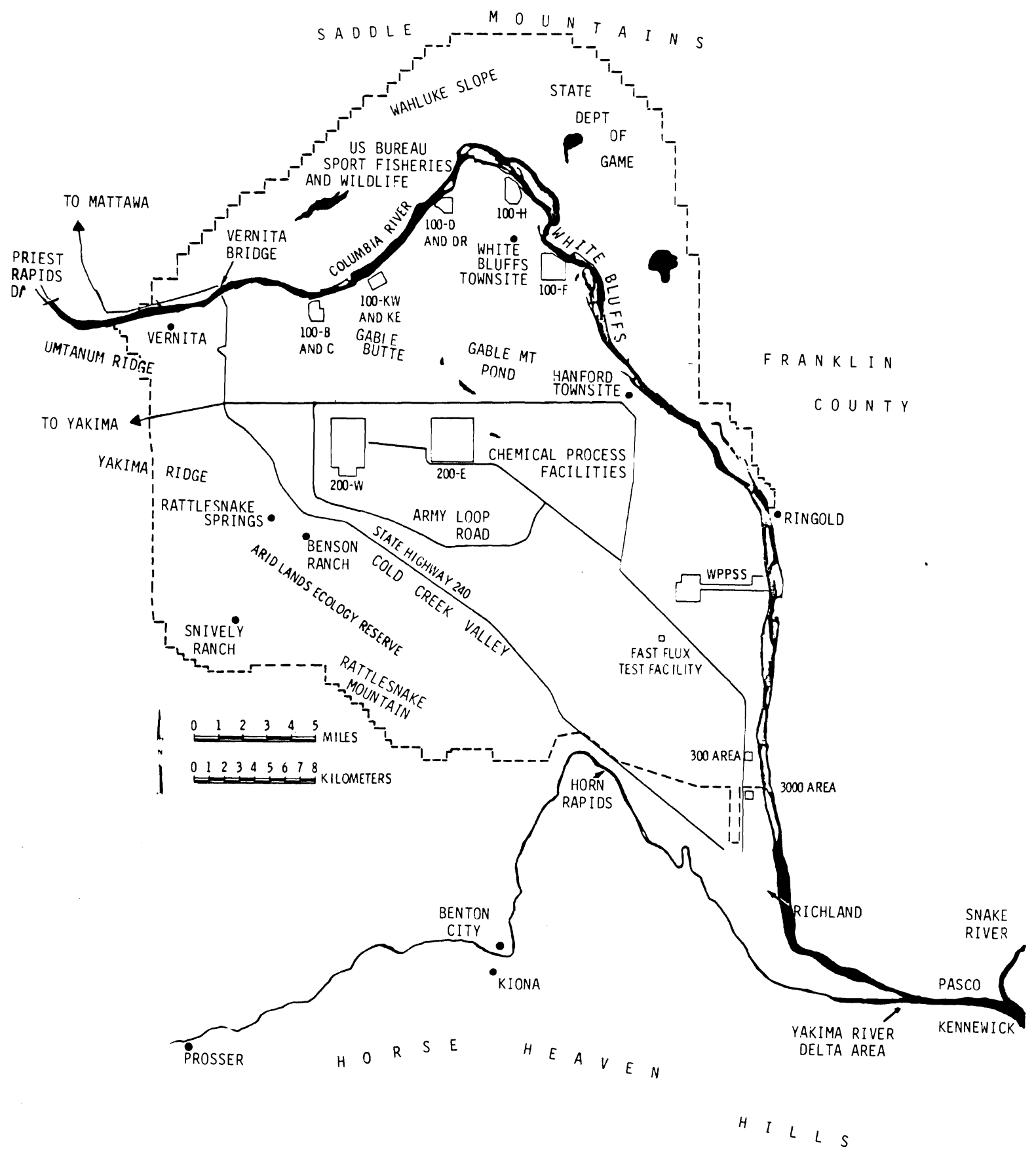

FIGURE 1. The Hanford Site 
Precipitation decreases after January but increases again to a secondary maximum in June. The climate of the Hanford Site can thus be described as consisting of hot, dry, summers and moderately cold winters. July is the hottest and driest month while January is the wettest and coldest (Thorp and Hinds 1977).

The vegetation of the Hanford Site can be characterized into three major community types (Figure 2). These are the sagebrush (Artemisia tridentata) bitterbrush (Purshia trindentata)/cheatgrass type (Bromus tectorum), the sagebrush/bluebunch wheatgrass (Agropyron spicatum) type and the sagebrush/ cheatgrass vegetation type (Cline et al. 1977).

The natural vegetation mosaic has been scarred by numerous fires and by past agricultural practices. Abandoned agricultural fields now dominated by cheatgrass and annual mustards are particularly noticeable. Trees appear erratically along both banks of the Columbia River from near shoreline to a few kilometers inland. Most of these trees were planted for shade or orchards by early settlers and were abandoned over 30 years ago with the creation of the Hanford Reservation (now called the Hanford Site). Trees also occur in other isolated spots around the site where they were planted as shade for industrial facilities and military installations, now decommissioned. The black locust (Robinia pseudoacacia), cottonwood (Populus sp.), apricot (Prunus sp.) and apple (Malus sp.) provide for much of the nesting of raptors. 


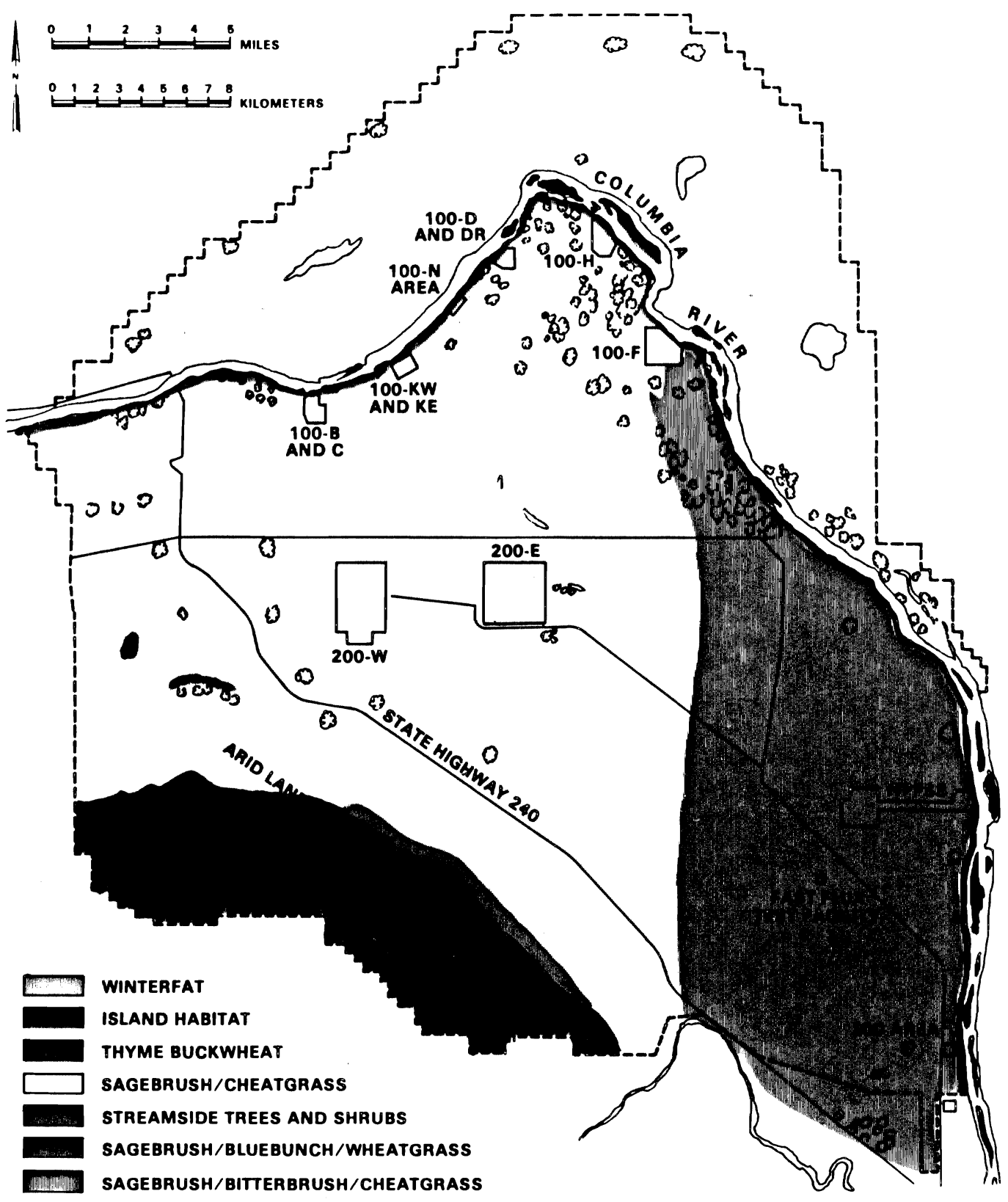

FIGURE 2. Plant Communities of the Hanford Site 


\section{METHODS}

This report summarizes data collected from 1973 through 1978. In 1973 and 1974 the entire Hanford Site was carefully surveyed for nesting sites. These two years provided the background information vital for carrying out a population study of the nesting birds of prey that live and interact together on the $1476 \mathrm{~km}^{2}$ study area known as the Hanford Site. Each year of the study an attempt was made to locate nests of all the raptors which used the Hanford Site during the breeding season. Considerable effort was also spent in determining the status of nonbreeding pairs and individuals. Certain raptors, notably the marsh hawk, short-eared owl and burrowing owl presented problems in surveying productivity determinators as their ground nests were difficult to locate. American kestrels often nested on high inaccessible cliffs or in dead trees and population data were also not always obtainable. Population density estimates for these species probably represent a minimum.

The intent of the study was to examine a population under natural conditions to gain accurate data on behavior and population productivity. Once nests were found their locations were mapped and visits were made to nest sites once during each of the following periods: nest building, egg laying and incubation, brood rearing, and post-fledgling periods. In this way precise data were gathered on behavior, clutch sizes, hatching success, and fledging success. Some raptor nests could not be reached and hence only data on fledging success were obtained. Throughout the study, care was taken to assure that the birds were not unnecessarily disturbed.

During the winter of 1976 , a 50 -mile census route was flown and all birds of prey encountered were recorded. The census line followed utility lines and incorporated trees bordering streams and along the Columbia River (Figure 1). A single engine, fixed-wing, airplane was flown at a speed of $85 \mathrm{mph}$ at an average height of 50 meters during each census. Observers sat on each side of the aircraft and recorded only raptors observed out their respective windows. The data gathered during these censuses provided some indication of seasonal species turnover and in a crude manner indicated the relative abundance of large diurnal raptors.

Food habits of owls were determined primarily from pellet analysis and to a lesser extent on prey remains observed at nests. Pellet analys is techniques described by Errington (1932) and Moon (1949) were employed in this study. Food habits of hawks were determined mostly from the tabulation of prey remains observed at nest sites and by observing captures. In the case of both the owl and hawk food habit data, relative frequency estimates were calculated for each prey taxon on the basis of total number identified (Curtis and McIntosh 1950).

Pellets from great horned, long-eared and barn owls and Swainson's and red-tailed hawks were analyzed for radionuclides. All samples were air dried at $50 \mathrm{C}$ for $48 \mathrm{hr}$ and then finely ground. Radiochemical analyses included an initial gamma scan of all samples using a NaI detector. Selected samples were reanalyzed using a system with a solid state primary detector coupled to a $\mathrm{NaI}$ detector for Compton's anticoincident correction. 
Five species of owls have been observed nesting on the Hanford Site. They include the great horned owl (Bubo virginianus), long-eared owl (Asio otus), short-eared owl (Asio flammeus), barn owl (Tyto alba) and burrowing owl (Athene cunicularia). The great horned and long-eared owls can be considered permanent residents on the site, while the remainder migrate to other areas during the winter. Four additional owl species have been recorded on or near the Hanford Site but have not been found nesting. The snowy owl (Nyctea scandiaca) is an infrequent winter visitor while the screech owl (0tus asio), saw-whet owl (Aegolius acadicus) and flammulated (0tus flammeolus) are infrequent spring and summer visitors. These latter three species may nest on the site but records are not available.

Six diurnal raptor species have been recorded nesting on the Hanford Site. These include the marsh hawk (Circus cyaneus), ferruginous hawk (Buteo regalis), red-tailed hawk (Buteo jamaicensis), Swainson's hawk (Buteo Swainsoni), prairie falcon (Falco mexicanus) and the American kestrel (Falco sparverius). These species, with the exception of the Swainson's hawk, have been recorded on the Hanford Site during every month of the year. Individuals seen during winter months, however, may not be the same ones observed nesting. Eleven other non-nesting diurnal raptors have been observed on the Hanford Site. The turkey vulture (Cathartes aura) is a rare springtime visitor. The goshawk (Accipiter gentilis), Cooper's hawk (A. cooper $i i)$ and sharp-shinned hawk (A. striatus) have been observed primariTy in riparian habitats from September through January. The rough-legged hawk (Buteo lagopus) is chiefly a winter visitor, and nests further north in Canada and ATaska.

The golden eagle (Aquila chrysaetos) has been observed during all months of the year but nesting on the Hanford Site was not observed during this study. Most spring and summer observations were of subadult birds. Adults are usually not seen until fall or winter seasons. The bald eagle (Haliaeetus leucocephalus) uses the Hanford reach of the Columbia River in winter. A group of 15 to 20 individuals stay on the Hanford Site from late November until late January (Fitzner and Hanson 1979). The osprey (Pandion haliaetus) is an uncommon visitor on the Hanford Site, but observations have been made during most months of the year. The gyrfalcon (Falco rusticolus) and peregrine falcon (Falco peregrinus) are rare winter visitors. During the course of this study, onty one individual of each species was recorded. The pigeon hawk (Falco columbarius richardsonii) and ( $F$. $c$. suckleyi) occur with irregularity on the site and all observations have been made during late fall.

Table 1 provides a taxonomic listing of all birds of prey that have been observed on the Hanford Site.

In order to understand the composite role of all the species of raptors using the Hanford Site, we present a general picture of the status and distribution of each species in South Central Washington and discuss briefly their individual biology. These species accounts are an introduction to a more generalized discussion of the ecology of the birds of prey on the Hanford Site. 
TABLE 1. Taxonomic Listing of the Birds of Prey of the Hanford Site

Genus

Species

ORDER - FALCONIFORMES

Family - Cathartidae

Cathartes aura

Turkey vulture

Family - Accipitridae

Accipiter gentilis

Goshawk

A. cooper $i \bar{i}$

$\bar{A}$. striatus

Circus cyaneus

Buteo lagopus

Buteo regalis

Buteo jamaicensis

Buteo swainsoni

Aquila chrysaetos

Haliaeetus leucocephalus

Pandion haliaetus

Falco rusticolus

Falco mexicanus

Falco peregrinus

Falco columbarius

Falco sparverius

Cooper's Hawk

Sharp-shinned hawk

Marsh hawk

Rough-legged hawk

Ferruginous hawk

Red-tailed hawk

Swainson's hawk

Golden eagle

Bald eagle

Osprey

Gyrfalcon

Prairie falcon

Peregrine falcon

Pigeon hawk

American kestrel

ORDER - STRIGIFORMES

Family - Strigidae

Otus asio

$\overline{\text { Otus }} \overline{\text { flammeolus }}$

Bubo virginianus

Asio otus

Asio flammeus

Nyctea scandiaca

Athene cunicularia

Aegolius acadicus

Screech ow 1

Flammulated ow 1

Great horned ow

Long-eared owl

Short-eared ow 1

Snowy ow 1

Burrowing ow 1

Saw-whet ow 1

Family - Tytonidae

Tyto alba

Barn owl

\section{TURKEY VULTURE}

The turkey vulture is a summer resident throughout washington, but it seems to be more common on the east side of the Cascades (Hudson and Yocom 1954, Jewett et al. 1953, Alcorn 1971). On the Hanford Site observations have 
been limited to April 11, May 4 and May 25 of 1978. Single birds were recorded each time. On April 11, a vulture was seen feeding on a road-killed blacktailed jackrabbit, Lepus californicus, by J. N. Fitzner, while the May observations were of soaring birds on the east slope of Rattlesnake Mountain.

The turkey vulture is often mistaken for an eagle due to its large size and black plumage. Its bare head, colored red-to-crimson, is not characteristic of the eagles, however. The turkey vulture also has claws, feet and bill which are much weaker than any of the other raptors found in washington. These anatomical features are adaptations for feeding on carrion.

\section{GOSHAWK}

The goshawk occurs in washington all year. They nest in forested regions but move down to the lowlands in winter. This species has often been observed along the Yakima River, particularly in the Benton City area (Figure 3). On the Hanford Site it has been observed only during late fall and winter months (October-March). Most observations have been made at Snively Gulch, a wooded streamside. Goshawks have also been observed hunting over sagebrush-bluebunch wheatgrass communities on other parts of the Arid Lands Ecology Reserve.

Goshawks are well adapted for feeding on medium sized birds and mammals. This species is capable of capturing grouse and rabbits on a regular basis. Chukar (Alectoris graeca), California quail (Lophortyx cal ifornicus), and Nuttall's cottontail (Sylvilagus nuttallii) are probably the important prey species on the Hanford Site.

\section{COOPER'S HAWK}

The Cooper's hawk is usually observed in riparian habitats, particularly along the lower reaches of the Yakima River and at Snively Gulch on the Hanford Site. Records of sightings are available from September through March. Infrequent sightings have been made in shrub-steppe habitats.

The Cooper's hawk feeds principally on birds of sparrow size. The species also feeds on small mammals. White-crowned sparrows (Zonotrichia leucophrys), mourning doves (Zenaidura macroura), and juncos (Junco hyemalis) have been recorded as prey on the Hanford Site.

\section{SHARP-SHINNED HAWK}

The sharp-shinned hawk occurs in the Columbia Basin during fall, winter, and early spring chiefly in riparian areas, being particularly abundant around the Benton City area in brushy sections adjacent to the Yakima Rivers. One subadult bird was banded in Snively Gulch on 5 September 1978. Numerous 


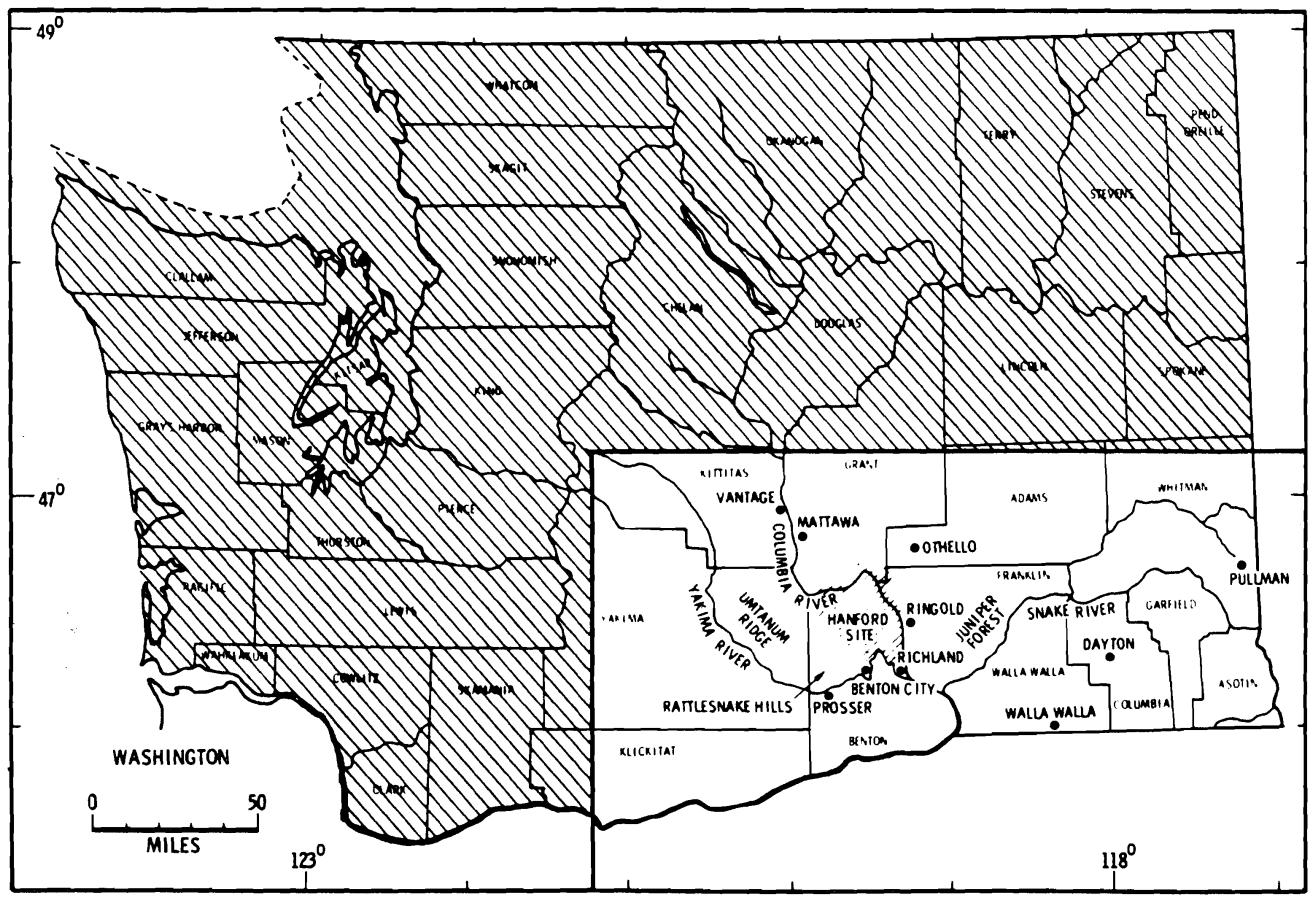

FIGURE 3. General study area where raptor sightings have been recorded sightings have been made in shrub-steppe and riparian habitats on the Hanford Site, particularly from September through March.

This accipiter feeds almost totally on small birds. No prey captures have been observed on the Hanford Site.

\section{MARSH HAWK}

Marsh hawks can be observed at any time of the year in the Columbia Basin. The winter population may represent the same individuals that nest in the basin, but data are lacking to substantiate this. Nesting occurs primarily in marshlands and in tall grassy fields. On the Hanford Site, the majority of nesting birds occur in Cold Creek Valley on the ALE reserve (Fig. 1). This valley is densely vegetated with cheatgrass and tumble mustard. Several pairs of birds also nest in native bluebunch wheatgrass communities on the sideslope of Rattlesnake Mountain. Islands in the Columbia River, particularly Numbers $6,8,13$, and 16 (Hanson and Eberhardt 1970) have supported nesting marsh hawks in the past.

Marsh hawks feed on small mammals and birds but are capable of catching small rabbits and quail. A female marsh hawk was observed killing a full grown Hungarian partridge (Perdix perdix) on the Hanford Site and marsh hawks have often been seen feeding on road-killed black-tailed jackrabbits and cottontails. 
AMERICAN ROUGH-LEGGED HAWK

This hawk is the most abundant buteo in the Columbia Basin during the winter, of ten being observed on the Hanford Site in early April with 1 May 1979 being the latest springtime record for Benton County. This bird was observed $2 \mathrm{mi}$. SW of Kiona, in a wheat field off McBee road above Horse Heaven Hills. Agricultural lands, particularly alfalfa fields, appear to be the most common habitat used by the birds for hunting. However, the American rough-legged hawk does not nest in washington.

American rough-legged hawks feed primarily on the small mammal genus Microtus while wintering in the Columbia Basin. Nearly twenty prey captures were observed during the 1970's and all were of Microtus sp. in alfalfa or grass fields. This raptor preys heavily on Microtus sp. and seems to have benefited from man's agricultural practices. Alfalfa and grain fields apparently resemble tundra habitats and grasslands on which this raptor nests. Physical similarity of the wintering agricultural lands in the Columbia Basin with the rough-legged hawk' ' nesting habitat may, in part, explain the large wintering numbers of this species in southcentral Washington. The added feature of an abundant prey base of Microtus $\mathrm{sp}$. enhances the Columbia Basin hay fields for wintering because microtines are an important prey of the rough-legged hawks on their nesting grounds (Springer 1975).

FERRUGINOUS HAWK

The ferruginous hawk is one of the largest hawks nesting in the Columbia Basin and is also rather uncommon. One nest is active on the Hanford Site. The presence of several old nests on Gable Butte and Rattlesnake Mountain indicates that more of the birds were present perhaps 10 or 20 years ago. In 1974 and 1975, Fitzner et a1. (1977) estimated that about 20 pair of these birds nested in washington state with the majority of the population occurring in Franklin County. Another intensive survey conducted in 1978 indicated that the population consisted of 26 pairs with 21 pairs having laid eggs. The areas surveyed in 1974 and 1975 were surveyed again in 1978 indicating that the population had slightly increased or that some ferruginous hawks were undetected in 1974 and 1975.

The increase in ferruginous hawks in washington in 1978 is perhaps a response to an increased prey base. In the 1978 nesting season, Townsend's and washington ground squirrels (Spermophilus townsendi $i$ and $\underline{S}$. Washington $i$ ) were noticeably abundant. Grass cuttings, burrows, and squirre 7 s were seen everywhere cheatgrass dominated a habitat. Observations at ferruginous hawk nests revealed that the hawks were feeding heavily on the squirrels. Field work in 1975 did not indicate any relationship with hawk production and ground squirrels. Other researchers (Howard and wolfe 1976) indicate that ferruginous hawks are quite dependent on a healthy prey base of medium-sized mammals for production. Years of low-mammal densities usually have low ferruginous hawk productivity. 
Ferruginous hawks nest on cliffs and trees and can even be found nesting on the ground. They occasionally build their nests low to the ground but usually build large stick nests in the crowns of trees.

\section{RED-TAILED HAWK}

The red-tailed hawk is perhaps the most frequently encountered large diurnal raptor in the Columbia Basin. It is the only large hawk commoniy found nesting in irrigated farmland. I have observed red-tailed hawks nesting within a few hundred meters of houses and main roads. Their only requirement for nesting seems to be a structure of suitable height. In over 50 nest sites examined in the past seven years, over 95 percent of all nests were found over 40 feet aboveground. The taller the nesting structure the more certain one can be of finding a pair of red-tailed hawks nesting in it. Lombardy poplars (Populus nigra) and cottonwoods ( . trichocarpa) tend to be the tallest of the trees found growing in the Columbia Basin and these form the bulk of the nesting structures. These hawks also nest in utility towers or on basalt and sandstone cliffs. Their ability to adapt to a wide variety of nesting structures enables them to exploit far more landscape than the more selective Swainson's and ferruginous hawks.

On the Hanford Site, red-tailed hawks nest principally in utility towers (30 to $100 \mathrm{ft}$ high), but several pairs nest on the Gable Butte complex, White Bluffs cliffs, and in the taller trees from Hanford townsite upriver to the 100-D Area.

Red-tailed hawks prey on a variety of organisms, but in the Columbia Basin they feed largely on jackrabbits, cottontails, ground squirrels, and snakes. This hawk appears to be one of the few raptor species that eats rattlesnakes; they are often crepuscular hunters. During very hot periods (above 100F), red-tailed hawks have been observed hunting mostly during early morning and late evening. Rattlesnakes are more active during night time and twilight periods when ground temperature is lowest, unlike western yellow-bellied racers (Coluber constrictor) and bullsnakes (Pituophis melanoleucus).

\section{SWAINSON'S HAWK}

The Swainson's Hawk is perhaps the most common of the three buteos that nest in the Columbia Basin. Between 15 and 18 pairs of Swainson's hawks nest on the Hanford Site. Nesting is restricted primarily to trees, however, and this limits the distribution of the species in areas dominated by rock outcroppings and cliffs. Most of the trees available for nesting were planted by man for shade or fruit. Without man's past activities, few pairs would be present on the Hanford Site today.

In the Columbia Basin, Swainson's hawks feed primarily on snakes (western yellow-bellied racers, bullsnakes) occasionally eating rabbits, small mammals, 
birds and insects. This hawk is migratory and can be found in washington from April to September. During the winter months the birds can be found in South America and sometimes in the southern United States and Mexico. Swainson's hawks usually nest in low growing trees, 8 to $30 \mathrm{ft}$ high. They construct a rather flimsy nest below the crown on a side branch (Fitzner 1980).

\section{AMERICAN KESTREL}

The American kestrel is one of the most abundant hawks nesting in the Columbia Basin. Nests have been seen in trees along the Yakima River from Prosser to Richland and elsewhere where hollow trees, magpie nests, buildings or cliffs provide cavities for nesting. On the Hanford Site, nesting occurs principally on the White Bluffs, in trees along the Columbia River from Hanford Townsite to the $100 \mathrm{D}$ area and in trees near Rattlesnakes Springs, Benson Ranch, and Snively Gulch.

The small size of the kestrel limits the size of the prey organism on which it can feed. Small vertebrates (lizards, birds, mice) and insects form the diet of this species.

PIGEON HAWK

Two races of this species have been observed on the Hanford Site: The black merlin (Falco columbarius suckleyi) and Richardson's merlin (F. C. richardsonii) and on ly during October through early December. F. C. suckleyi is most often observed particularly in the shelter belt area of $\mathrm{Rich}$ and and along the lower reaches of the Yakima River. Neophyte bird watchers often mistake this bird for a peregrine falcon even though it is much smaller and colored somewhat differently. F. C. richardsonii is more likely to be seen in sagebrush-bunchgrass areas not $\bar{f}$ ar from riparian habitats. Neither of these two pigeon hawk races nests on the Hanford Site, although $\underline{F}$. $\underline{c}$. richardsoni $\underline{i}$ may nest in Franklin County.

The small pigeon hawk preys chiefly on birds, and is quite capable of capturing meadowlarks. Both races have been observed capturing small birds and a Richardson's merlin was seen feeding on a white-crowned sparrow (Zonotrichia leucophrys) on one occasion.

\section{PRAIRIE FALCON}

This is perhaps one of the rarest of the nesting raptors on the Hanford Site. No more than four pairs have ever been found nesting on the Hanford Site during any one year. 0lendorff (1973a) felt that as many as seven pairs were present and that most of these occurred along Umtanum ridge between Priest Rapids Dam and the Vernita bridge. During six years of intensive field inves- tigation, 3 pairs were all that were ever located in that stretch of cliff line. The Gable Mountain-Gable Butte complex, White Bluffs, and Rattlesnake Mountain have also been used for nesting and are the principal habitats for the nesting of prairie falcons on the Hanford Site. 
The habit of nesting on cliffs limits the spectrum of nest sites available to this raptor and hence limits the birds' distribution during the nesting season. The selection of cliff-nesting sites does, however, provide more protection for the eggs and young from natural predators and man than can be afforded to the tree-nesting raptors. Unless efforts are taken to assure that the few cliff-nesting sites are protected from human disturbance, this raptor may disappear from the Hanford Site.

Prairie falcons feed on a variety of small mammals and birds, particu1 arly pocket gophers (Thomomys talpoides) and cottontail rabbits. The abundant prey resources available on the Hanford Site do not appear to be a limiting factor in the size of the present breeding population.

OSPREY

The osprey has not been recorded nesting in the Columbia Basin; however, sightings of adult birds during the breeding season are not uncommon. A lack of suitable nest sites and/or prey base could be important reasons for the osprey's absence as a nesting species. During July and August, sightings of ospreys become more prevalent and as fall approaches, ospreys are rather common along the Columbia, Snake and Yakima Rivers of the Columbia Basin. Observations have also been made during the winter and early spring months. Most sightings on the Hanford Site occurred within $2 \mathrm{~km}$ of the Columbia River.

During the course of these studies of raptors on the Hanford Site, well over two dozen ospreys have been observed feeding on prey. In all cases, fish were the only organisms eaten. Suckers (Catastomus sp.) appeared to comprise the major part of the osprey's diet.

\section{GOLDEN EAGLE}

Golden eagles are present year around on the Hanford Site, but nesting occurs in adjacent areas where high cliffs are present. Most golden eagle sightings were made on the Hanford Site from late fall to early March and most were of juvenile birds. Two areas most heavily used by the golden eagles are the ALE Reserve and the 1 and between the 300 Area and Hanford Townsite extending from the Columbia River inland about $5 \mathrm{~km}$. Approximately 8 to 10 golden eagles winter on the Hanford Site. Artificial nesting structures placed on Rattlesnake Mountain might induce eagles to nest. Little is known about daily or seasonal movements of these birds.

Golden eagles are principally medium-sized mammal consumers, feeding heavily on black-tailed jackrabbits. They have been observed feeding on roadkilled deer and jackrabbits and have also been seen capturing jackrabbits and robbing food (snakes) from young nestling Swainson's hawks. 


\section{BALD EAGLE}

Bald eagles occur in the Columbia Basin and on the Hanford Site primarily during winter months. They are found near waterways particularly along the Hanford reach of the Columbia River. Fitzner and Hanson (1979) reported that as many as 20 bald eagles winter on the Hanford reach. No data are available for the Hanford Site on daily or seasonal movement patterns of this species. This is the only species occurring on the Hanford Site that is Federally classified as "threatened" (50 CFR 17). Nesting was reported for the Hanford Site during the 1960s, but according to W. C. Hanson, a PNL ecologist, no birds have nested here since that time.

Bald eagles are quite dependent on fish as their food. Waterfowl, rabbits, and carrion may also become important seasonally, but fish seem to be preferred (Fitzner and Hanson 1979).

\section{GREAT HORNED OWL}

The great horned owl is not abundant on the Hanford Site, due to a scarcity of heavily wooded habitats and cliffs. Great horned owls have been found using riparian canyons on the slopes of Rattlesnake Mountain, wooded areas along the Columbia River from Hanford townsite upstream to the Vernita bridge, on Gable Butte and White Bluffs and retired buildings associated with the 100 Areas. Other areas of the Columbia Basin where great horned owls commonly occur are wooded banks of the Yakima River, the Juniper Forest in southern Franklin County; and cliffs along the Snake and Columbia Rivers and in the channeled scablands (U.S.D.I. 1973) of southeastern Washington.

When these large owls were first studied on the Hanford Site, their numbers seemed to be increasing. Since 1976, the population of 12 birds has dropped to 7 in 1978. The number of nesting pairs has also declined from five to three pairs. This reduction appears to be directly related to human disturbance. A pair that of ten used the $100 \mathrm{D}$ area buildings for roosting and nesting may have been driven away by decommissioning activities along the Columbia River near that area. Decommissioning activities elsewhere along the Columbia River may also have disturbed other great horned owls. A DOE-supported project has been to erect signs to alert workmen and others to sensitive wildlife areas where offroad travel and disturbance to wildlife are prohibited.

Great horned owls feed on a variety of prey organisms and seem to be capable of capturing animals ranging in size from jackrabbits to insects. On a numerical basis, the Great Basin pocket mouse (Perognathus parvus) was frequently captured, but lagomorphs were of greater importance on a biomass basis.

\section{LONG-EARED OWL}

On the Hanford Site, long-eared owls occur only in areas where trees are present. Abandoned orchards, homesteads, and the Hanford Townsite are the 
primary use areas for nesting and roosting, with Snively Canyon and Rattlesnake Springs on the Arid Lands Ecology Reserve also receiving some use. Here again is a species which has particularly benefited from man's plantings of trees. In pre-Caucasian times, trees were no doubt scarce in the Hanford Area and long-eared owls were limited to natural riparian habitats. Long-eared owls occur throughout the Columbia Basin, whenever trees occur and man's activities are minimized or absent. The Yakima delta area of Richland and the Juniper Forest of southern Franklin County are heavily used for nesting and roosting by this owl.

Over 90 percent of this owl's diet consists of pocket mice and deer mice (Peromyscus maniculatus) with pocket mice forming the bulk of the diet.

\section{SHORT-EARED OWL}

The short-eared ow 7 is a common winter visitor in the Columbia Basin, but is an uncommon breeding species. Marshlands and irrigated pasture lands and alfalfa fields are common nesting habitats in the basin. During the winters of 1973, 1975 and 1977, short-eared owls were very abundant in farmlands from Vantage to Othello. Tremendous influxes of short-eared owls occur during the winter in the agricultural lands near Royal City in Grant County. The marshes and alfalfa fields which abound in this area support high populations of microtines which form an important component of the short-eared owls diet (Fitzner and Fitzner 1975). The Hanford Site does not support many wintering or nesting short-eared owls. Pristine habitats do not seem to attract this species as well as farm lands and marshes. Again, this is probably related to the availability of prey (microtines) but could also be related to the structure of vegetational associations. Wintering birds may be attracted to areas which resemble tundra. Many of these wintering short-eared owls are probably birds which nested far north in Canadian tundra and in moving south during winter, they naturaliy select habitats which resemble areas they have previously experienced.

The short-eared ow 1 is primarily diurnal as is their major prey source microtines. Fitzner and Fitzner (1975) found that this owl feeds on small mammals roughly in the same frequency as they occur in the environment.

BARN OWL

Barn owls are common in the Columbia Basin and should be considered a resident species. An influx of birds may occur in the spring as a migrant group returns to breed. This species has been found nesting on basalt cliffs, in old barns, buildings, hay stacks, and in magpie nests, and has been observed at all seasons of the year.

On the Hanford Site, barn owls are most often seen in old buildings around the 100 Areas, and in reactor outflows along the Columbia River. Rattlesnake Springs is often used by the species. Between two and four pairs reside on the Hanford Site. 
Barn owls, like long-eared owls, are almost totally mouse hunters. In pristine shrub-steppe habitats, they feed mostly on Great Basin pocket mice. In farmlands, the house mouse (Mus musculus) replaces the pocket mouse as the major prey species. Unlike the long-eared owl, barn owls were not found to feed on insects, and their diet was also more restricted in the diversity of prey.

FLAMMULATED OWL

The flammulated owl is uncommon in the Columbia Basin but occurs as a summer resident in the Blue Mountains (Hudson and Yocom 1954). Only one record exists for the Hanford Site. On March 5, 1972, a single bird was observed in a rocky gulch near Bobcat Canyon on the side slopes of Rattlesnake Mountain and photographed by Dr. T. P. O'Farrell. Flammulated owls are probably more abundant than records indicate since they are rather secretive and cryptically colored. In the Columbia Basin, the species is probably a migrant.

This small dark-eyed owl nests in cavities of trees or stumps in wooded and brushy areas. They are largely insectivorous, but occasionally take small mammals or birds (Eyre and Paul 1973).

SAW-WHET OWL

An adult saw-whet owl was banded on July 17, 1978 in Snively Canyon on the sideslopes of Rattlesnake Mountain. In the Columbia Basin, the species is probably a common migrant in riparian areas and Juniper habitats. Hudson and Yocom (1954) also report a breeding record for nearby Dayton, in Columbia County.

The saw-whet owl is primarily a forest dweller where it feeds on small mammals (Microtus, Peromyscus, Sorex) and small birds (Forsman and Maser 1970).

\section{SNOWY OWL}

Snowy owls nest in the arctic regions of North America, but incursions into Washington and the Columbia Basin have been reported (Hanson 1971). During this study, few records were reported for the Columbia Basin. One or two reports of large white owls occurred each winter but there was no large influx of birds as reported by Hanson (1971). Only one record exists for the Hanford Site since 1973 when a single bird was observed on top of Rattlesnake Mountain by J. T. Rotenberry.

This species feeds on a variety of small mammals, birds, and lagomorphs. In the arctic, lemmings (Lemmus spp.), ptarmigan (Lagopus spp.), and snowshoe hares (Lepus americanus) are important prey. In examination of castings I collected near Pullman, Washington, Microtus montanus was found to be the major prey item. 
BURROWING OWL

This small owl is perhaps the most abundant owl nesting in the Columbia Basin and is certainly the most common owl nesting on the Hanford Site. Between 20 and 26 nesting pairs occur on the Hanford Site. Badger (Taxidea taxus) and coyote (Canis latrans) burrows provided most of the nest sites. This species has been observed wintering around Benton City and Mattawa and at least one pair has been observed near Benton City every winter since 1973. These birds used a badger hole for shelter. Woodby (1976) reported on several other winter records for burrowing owls in eastern Washington.

Burrowing owls feed on insects and small mammals, taking a larger number and greater diversity of insects than they do mammals. Mammals, however, form the bulk of their diet on a biomass basis.

SCREECH OWL

There are no sight records for this small owl from the Hanford Site. However, two adults have been observed near Benton City. The birds (observed on different occasions) were associated with farming lands interspersed with groves of deciduous trees planted by man or occurring naturally along the banks of the Yakima River.

Screech owls nest mostly in cavities of trees, but readily accepted artificial nest boxes (VanCamp and Henry 1975). The diet of this species consists mostly of small mammals and birds (Smith and Wilson 1971). 


\section{POPULATION AND PRODUCT IV ITY}

\section{POPULATION DATA}

During the four years of study, a total of 12 great-horned ow 1 nesting sites were found. No more than 7 pairs of birds were observed during any one year. Fourteen different nest sites were used by long-eared owls with no more than 8 pairs being observed in a given year. Only two pairs of short-eared owls were observed nesting during each year of the study. Four nest sites were observed but never more than two pairs were found nesting. Burrowing owls were the most abundant owl nesting on the site. No fewer than 20 pairs were found nesting during each year of the study. The burrow nest sites of this small raptor were difficult to find and estimates of their breeding density are minimum values. The nest site locations of owls for 1975 through 1978 are presented in Figures 4 through 7. Productivity data are given in Table 2 and yearly summaries of nesting success are presented in Tables 3 through 6 .

Diurnal raptors formed the bulk of the nesting raptor population on the Hanf ord Site. The two buteo species, red-tailed hawk and Swainson's hawk, dominated the scene. In 1975, 9 pairs of red-tailed hawks displayed a dramatic increase to 16 pairs in 1976 reaching a peak of 25 pairs in 1977 . Swainson's hawks remained at nearly the same level, decreasing only slightly to 15 pairs in 1977. No more than 3 pairs of prairie falcons were ever recorded on the Hanford Site. Densities of marsh hawks and American kestrels were only estimated since nests of these species were difficult to find. These estimates, therefore, probably reflect the minimum yearly populations levels. Productivity data are provided in Table 7 and yearly summaries of nesting success are given in Tables 8 through 11. Nest site locations for diurnal raptors are shown in Figures 8 through 12 .

During the four years of intensive field investigation (1975-1978), five owl (strigif ormes) species (great-horned, long-eared, short-eared, barn, burrowing) and five hawk (falconiformes) species (marsh, red-tailed, Swainson's, prairie falcon, American kestrel) nested on the Hanford Site. All of these species nested during each of the four study years. Red-tailed hawks displayed the greatest increase in population size over the four-year period, beginning with 19 recorded individuals ( 9 pair and 1 single bird) in 1975, peaking at 50 in 1977 and dropping slightly to 45 in 1978 (Table 12). This increase is correlated with the elimination of disturbances from humans during the nesting season. During the early 1970's local power companies removed nests from utility poles and towers on the Hanford Site, believing them to be fire hazards. In 1974, this policy was discovered by researchers studying Hanford raptors and they requested that power company officials stop the practice. The result was a near 3-fold increase in the population of red-tailed hawks within three nesting seasons; clearly the red-tail population responded to the elimination of human disturbance during the nesting season. 0 ther factors may have been partially responsible for the increase in nesting 


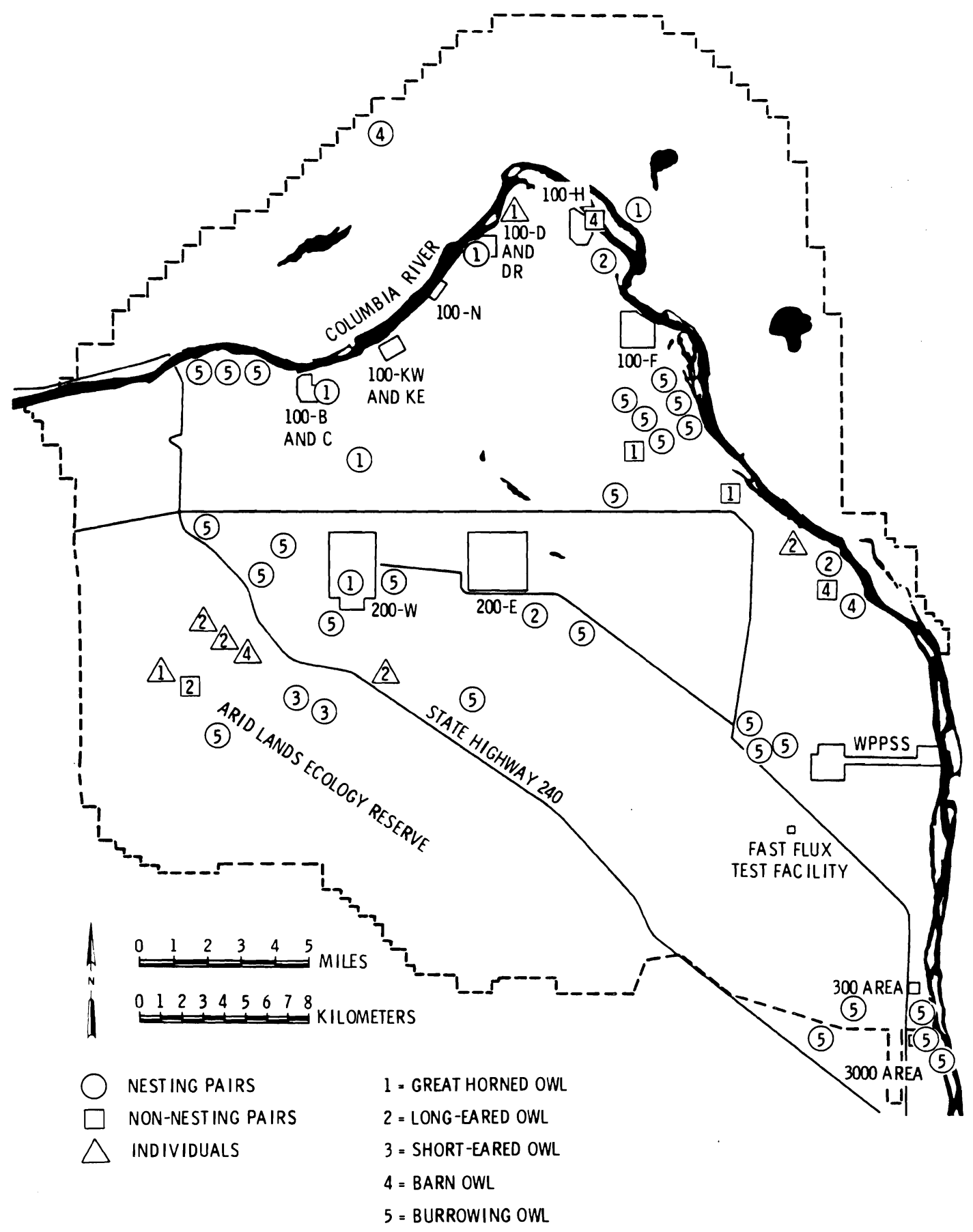

FIGURE 4. Locations of Nesting and Non-nesting Pairs and Single Ow7s - 1975 


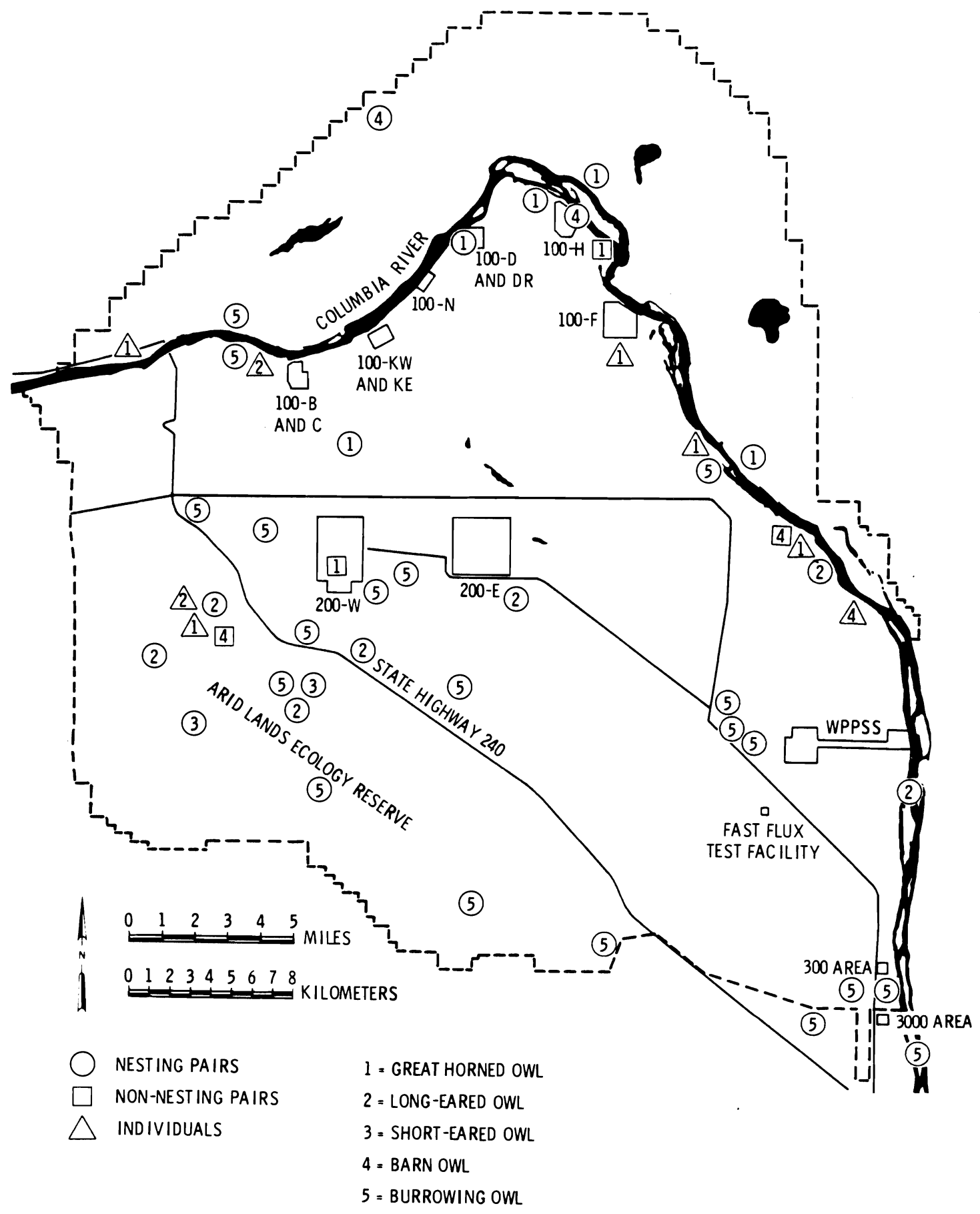

FIGURE 5. Locations of Nesting and Non-nesting Pairs and Single Owls - 1976 


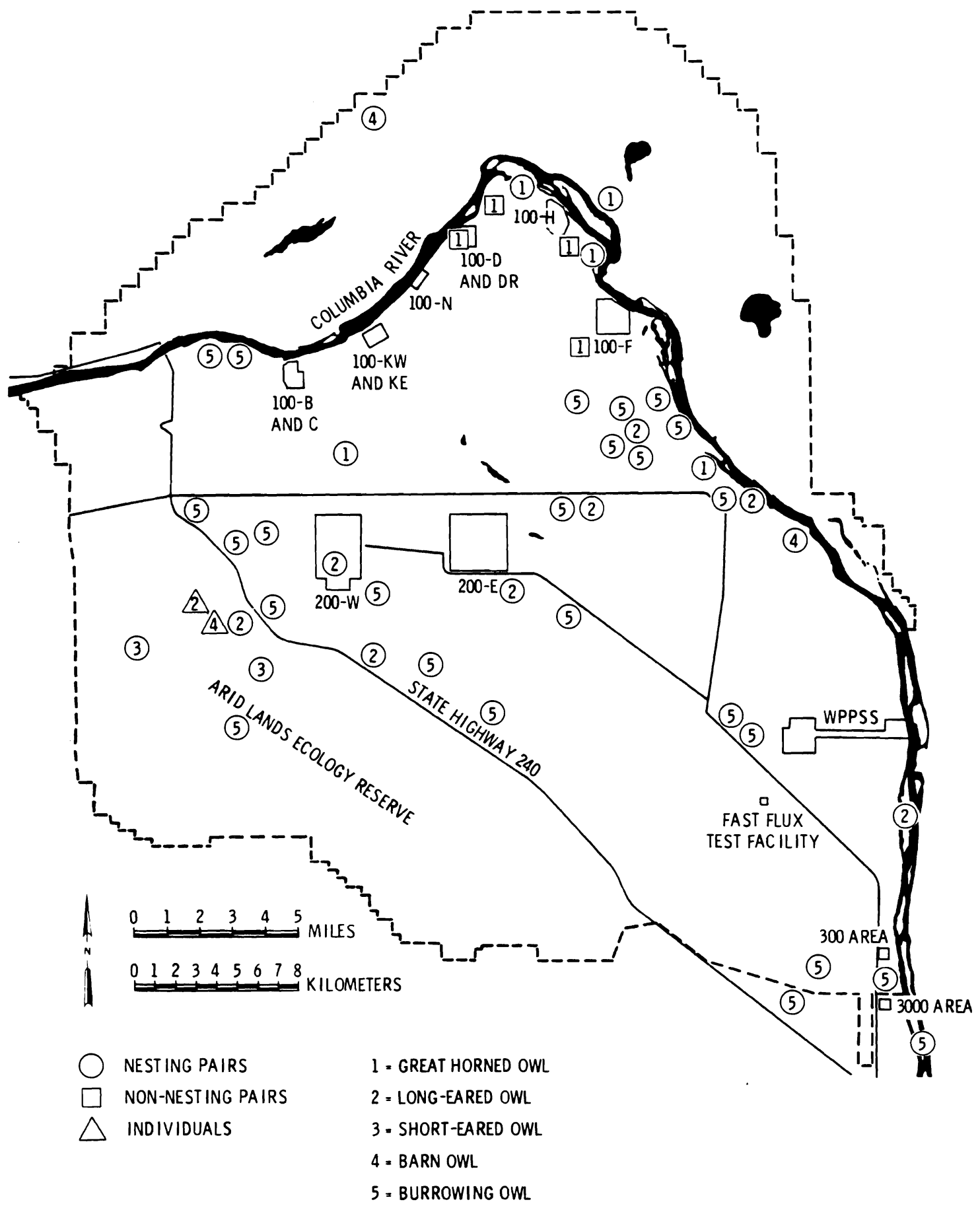

FIGURE 6. Locations of Nesting and Non-nesting Pairs and Single Ow1s - 1977 


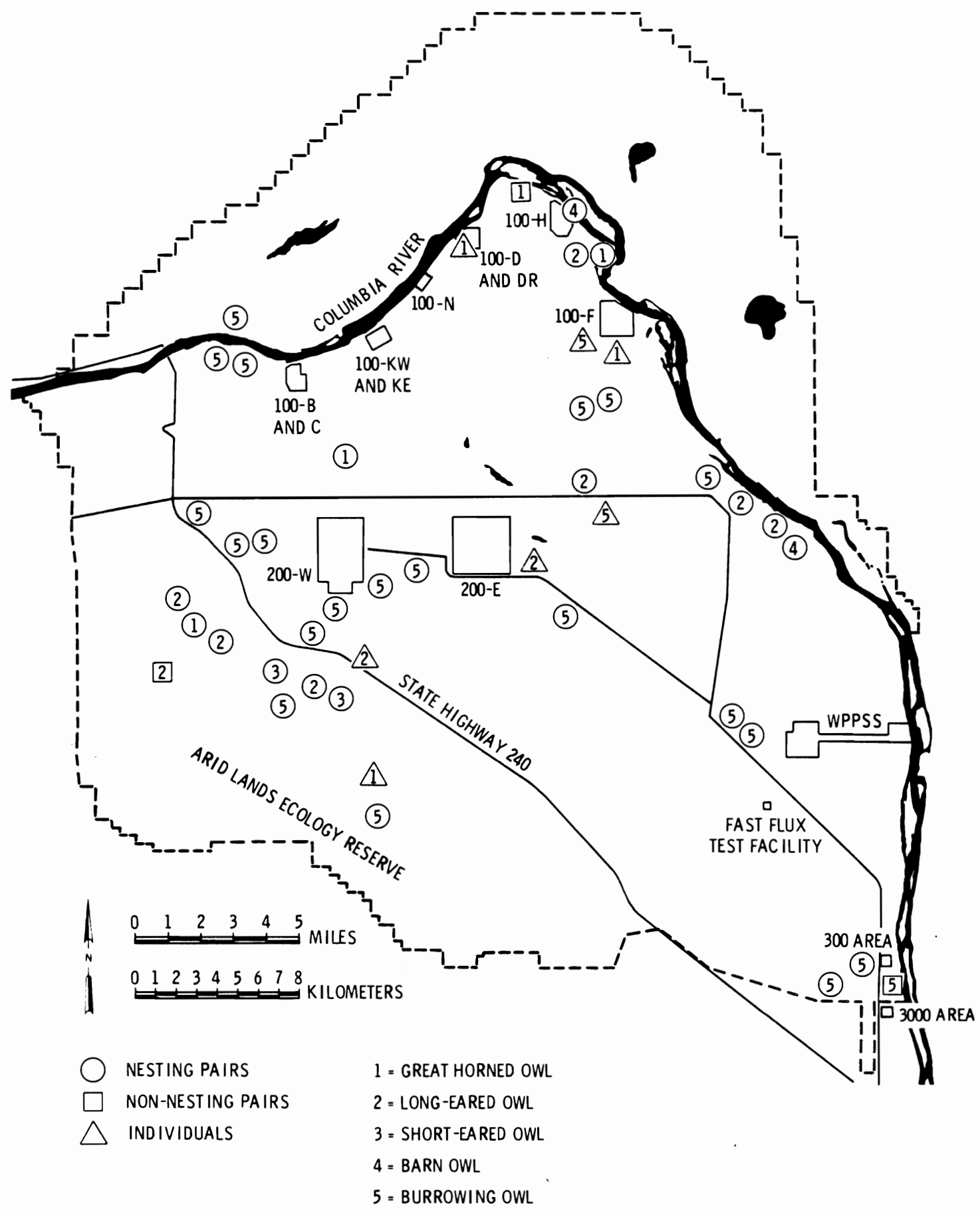

FIGURE 7. Locations of Nesting and Non-nesting Pairs and Single Owls - 1978 
TABLE 2. Productivity of OWTs 1975-1978

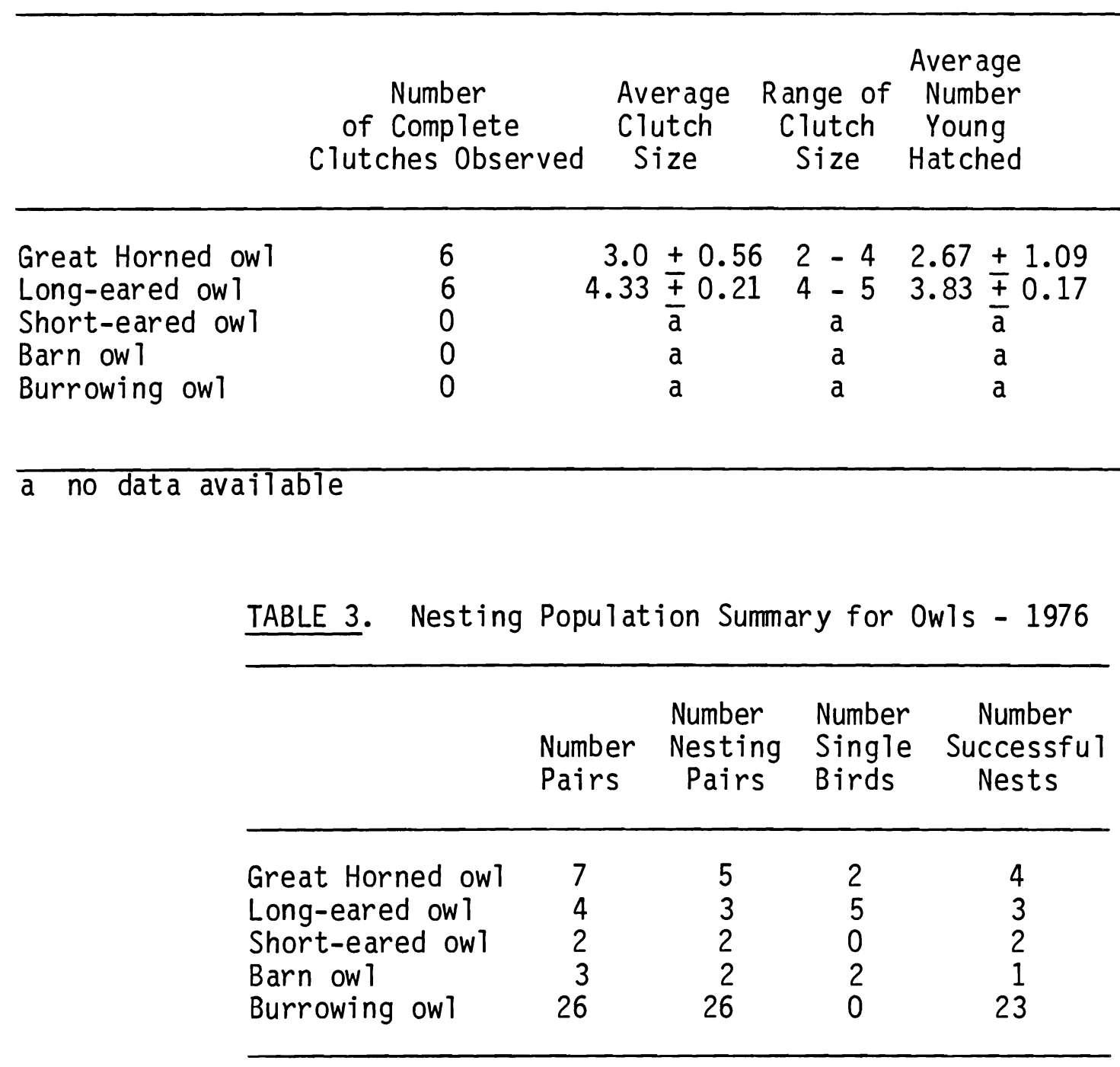

TABLE 4. Nesting Population Summary for Owls - 1977

\begin{tabular}{|c|c|c|c|c|}
\hline & $\begin{array}{l}\text { Number } \\
\text { Pairs }\end{array}$ & $\begin{array}{l}\text { Number } \\
\text { Nesting } \\
\text { Pairs }\end{array}$ & $\begin{array}{l}\text { Number } \\
\text { Single } \\
\text { Birds }\end{array}$ & $\begin{array}{c}\text { Number } \\
\text { Successful } \\
\text { Nests }\end{array}$ \\
\hline $\begin{array}{l}\text { Great Horned ow } 1 \\
\text { Long-eared ow } 1 \\
\text { Short-eared ow } 1 \\
\text { Barn ow } 1 \\
\text { Burrowing owl }\end{array}$ & $\begin{array}{r}7 \\
8 \\
2 \\
4 \\
20\end{array}$ & $\begin{array}{r}5 \\
8 \\
1 \\
2 \\
20\end{array}$ & $\begin{array}{l}5 \\
2 \\
1 \\
1 \\
0\end{array}$ & $\begin{array}{r}5 \\
8 \\
1 \\
2 \\
16\end{array}$ \\
\hline
\end{tabular}


TABLE 5. Nesting Population Summary for Ow1s - 1978

\begin{tabular}{lcccc}
\hline & $\begin{array}{l}\text { Number } \\
\text { Pairs }\end{array}$ & $\begin{array}{l}\text { Number } \\
\text { Nesting } \\
\text { Pairs }\end{array}$ & $\begin{array}{l}\text { Number } \\
\text { Single } \\
\text { Birds }\end{array}$ & $\begin{array}{c}\text { Number } \\
\text { Successfu1 } \\
\text { Nests }\end{array}$ \\
\hline Great Horned ow1 & 5 & 5 & 5 & 4 \\
Long-eared ow 1 & 8 & 8 & 1 & 8 \\
Short-eared ow1 & 2 & 2 & 0 & 2 \\
Barn ow1 & 2 & 2 & 1 & 1 \\
Burrowing ow & 25 & 25 & 0 & 22 \\
\hline
\end{tabular}

TABLE 6. Nesting Population Summary for Owls - 1978

\begin{tabular}{lcccc}
\hline \multicolumn{1}{c}{ Species } & $\begin{array}{c}\text { Number } \\
\text { of Pairs }\end{array}$ & $\begin{array}{c}\text { Number of } \\
\text { Nesting Pairs }\end{array}$ & $\begin{array}{c}\text { Number of } \\
\text { Single Birds }\end{array}$ & $\begin{array}{c}\text { Number of } \\
\text { Successfut Nests }\end{array}$ \\
\hline Great Horned ow 1 & 4 & 3 & 3 & 2 \\
Long-eared ow 1 & 8 & 7 & 2 & 6 \\
Short-eared ow 1 & 2 & 2 & 0 & 2 \\
Barn ow & 2 & 2 & 0 & 19 \\
Burrowing ow 1 & 21 & 20 & 2 & \\
\hline
\end{tabular}

TABLE 7. Productivity of Hawks 1975-1978

\begin{tabular}{|c|c|c|c|c|c|}
\hline & $\begin{array}{l}\text { Number Complete } \\
\text { Clutches Observed }\end{array}$ & $\begin{array}{c}\text { Average Clutch } \\
\text { Size }\end{array}$ & $\begin{array}{l}\text { Range of Clutch } \\
\text { Size }\end{array}$ & $\begin{array}{l}\text { Average Number } \\
\text { Young Hatched }\end{array}$ & $\begin{array}{l}\text { Average Number } \\
\text { Young Fledged }\end{array}$ \\
\hline Marsh hawk & 2 & 4 & 4 & 4.0 & 4.0 \\
\hline Red-tailed hawk & 19 & $\begin{array}{l}2.31 \pm 0.205 \\
n=19\end{array}$ & $1-4$ & $2.07 \pm 0.203$ & $1.85 \pm 0.231$ \\
\hline Swainson's hawk & 39 & $2.18 \pm 0.137$ & $1-4$ & $1.92 \pm 0.153$ & $1.85 \pm 0.154$ \\
\hline Prairie falcon & 3 & $4.33 \pm 0.333$ & $4-5$ & $3.67 \pm 0.882$ & $3.00 \pm 1.528$ \\
\hline American kestrel & 0 & $\mathrm{a}$ & $\mathrm{a}$ & $\mathrm{a}$ & $\begin{array}{l}4.0 \pm 0.41 \\
n=4\end{array}$ \\
\hline
\end{tabular}


TABLE 8. Nesting Population Summary for Hawks - 1975

\begin{tabular}{lrrrr}
\hline \multicolumn{1}{c}{ Species } & $\begin{array}{c}\text { Number } \\
\text { Pairs }\end{array}$ & $\begin{array}{c}\text { Number } \\
\text { Nesting } \\
\text { Pairs }\end{array}$ & $\begin{array}{c}\text { Number } \\
\text { Single } \\
\text { Birds }\end{array}$ & $\begin{array}{c}\text { Number } \\
\text { Successfu1 } \\
\text { Nests }\end{array}$ \\
\hline Marsh hawk & 5 & 5 & $a$ & 5 \\
Red-tailed hawk & 9 & 8 & 1 & 8 \\
Swainson's hawk & 17 & 16 & 1 & 13 \\
Prairie falcon & 2 & 2 & 0 & 2 \\
American kestrel & 10 & 10 & $a$ & 10 \\
\hline
\end{tabular}

a no data available

TABLE 9. Nesting Population Summary for Hawks - 1976

\begin{tabular}{lrrrr}
\hline \multicolumn{1}{c}{ Species } & $\begin{array}{c}\text { Number } \\
\text { Pairs }\end{array}$ & $\begin{array}{c}\text { Number } \\
\text { Nesting } \\
\text { Pairs }\end{array}$ & $\begin{array}{c}\text { Number } \\
\text { Single } \\
\text { Birds }\end{array}$ & $\begin{array}{c}\text { Number } \\
\text { Successfu1 } \\
\text { Nests }\end{array}$ \\
\hline Marsh hawk & 5 & 5 & $\mathrm{a}$ & 5 \\
Red-tailed hawk & 17 & 15 & 1 & 13 \\
Swainson's hawk & 16 & 14 & 0 & 13 \\
Prairie falcon & 2 & 2 & 0 & 1 \\
American kestrel & 10 & 10 & a & 10 \\
\hline
\end{tabular}

a no data available 
TABLE 10. Nesting Population Summary for Hawks - 1977

\begin{tabular}{lrrrr}
\hline \multicolumn{1}{c}{ Species } & $\begin{array}{c}\text { Number } \\
\text { Pairs }\end{array}$ & $\begin{array}{c}\text { Number } \\
\text { Nesting } \\
\text { Pairs }\end{array}$ & $\begin{array}{c}\text { Number } \\
\text { Single } \\
\text { Birds }\end{array}$ & $\begin{array}{c}\text { Number } \\
\text { Successfu1 } \\
\text { Nests }\end{array}$ \\
\hline Marsh hawk & 5 & 5 & a & 5 \\
Red-tailed hawk & 25 & 22 & 0 & 19 \\
Swainson's hawk & 15 & 9 & 0 & 9 \\
Prairie falcon & 2 & 2 & 0 & 2 \\
American kestrel & 10 & 10 & $a$ & 10 \\
\hline
\end{tabular}

a no data available

TABLE 11. Nesting Population Summary for Hawks - 1978

\begin{tabular}{lrrrr}
\hline \multicolumn{1}{c}{ Species } & $\begin{array}{c}\text { Number } \\
\text { Pairs }\end{array}$ & $\begin{array}{c}\text { Number } \\
\text { Nesting } \\
\text { Pairs }\end{array}$ & $\begin{array}{c}\text { Number } \\
\text { Single } \\
\text { Birds }\end{array}$ & $\begin{array}{c}\text { Number } \\
\text { Successful } \\
\text { Nests }\end{array}$ \\
\hline Marsh hawk & 5 & 5 & $a$ & 5 \\
Red-tailed hawk & 22 & 20 & 1 & 17 \\
Swainson's hawk & 18 & 17 & 1 & 12 \\
Prairie falcon & 3 & 3 & 0 & 2 \\
American kestrel & 10 & 10 & a & 10 \\
\hline
\end{tabular}

a no data available 


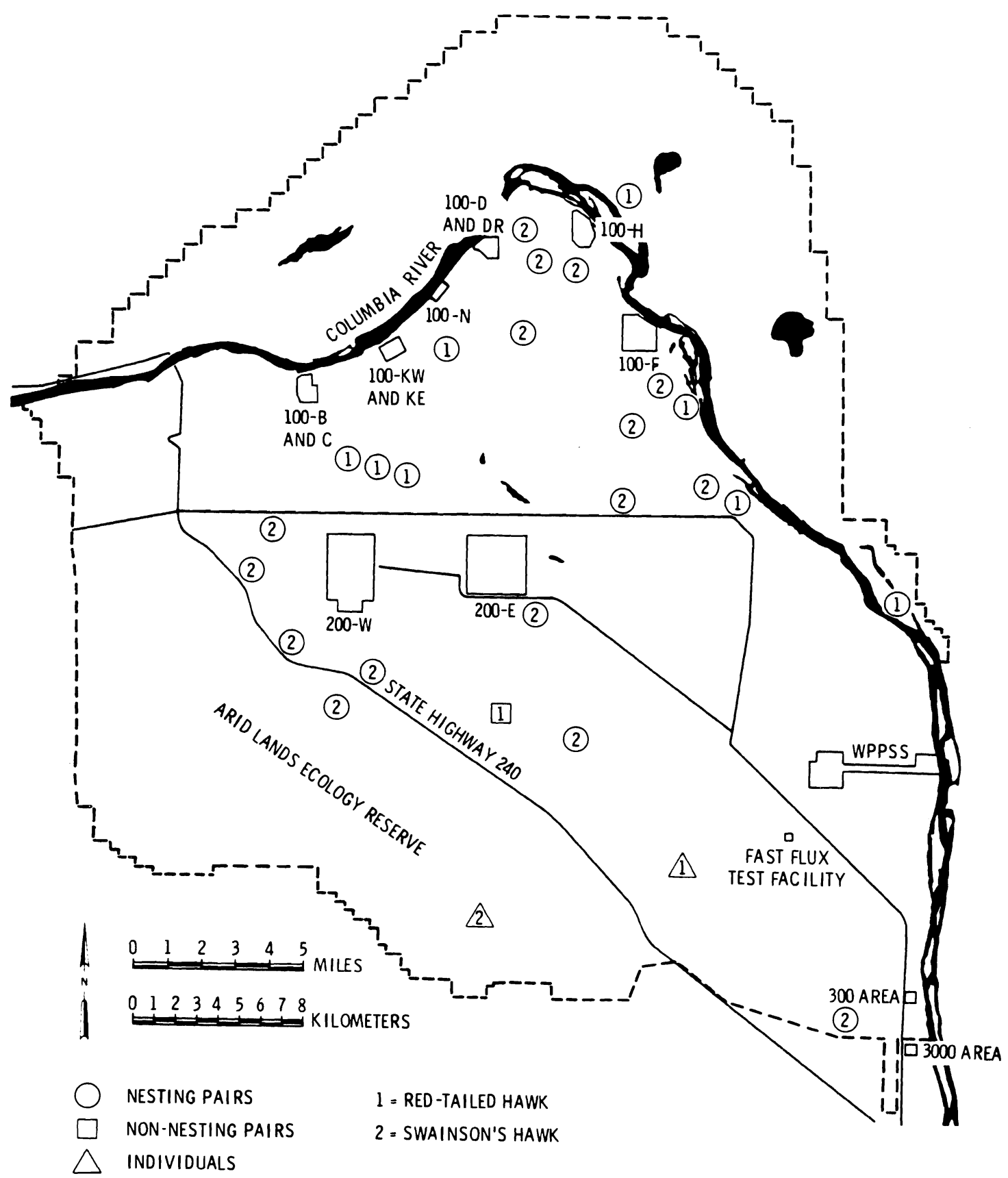

FIGURE 8. Locations of Nesting and Non-nesting Pairs and Single Red-tailed and Swainson's Hawks - 1975 


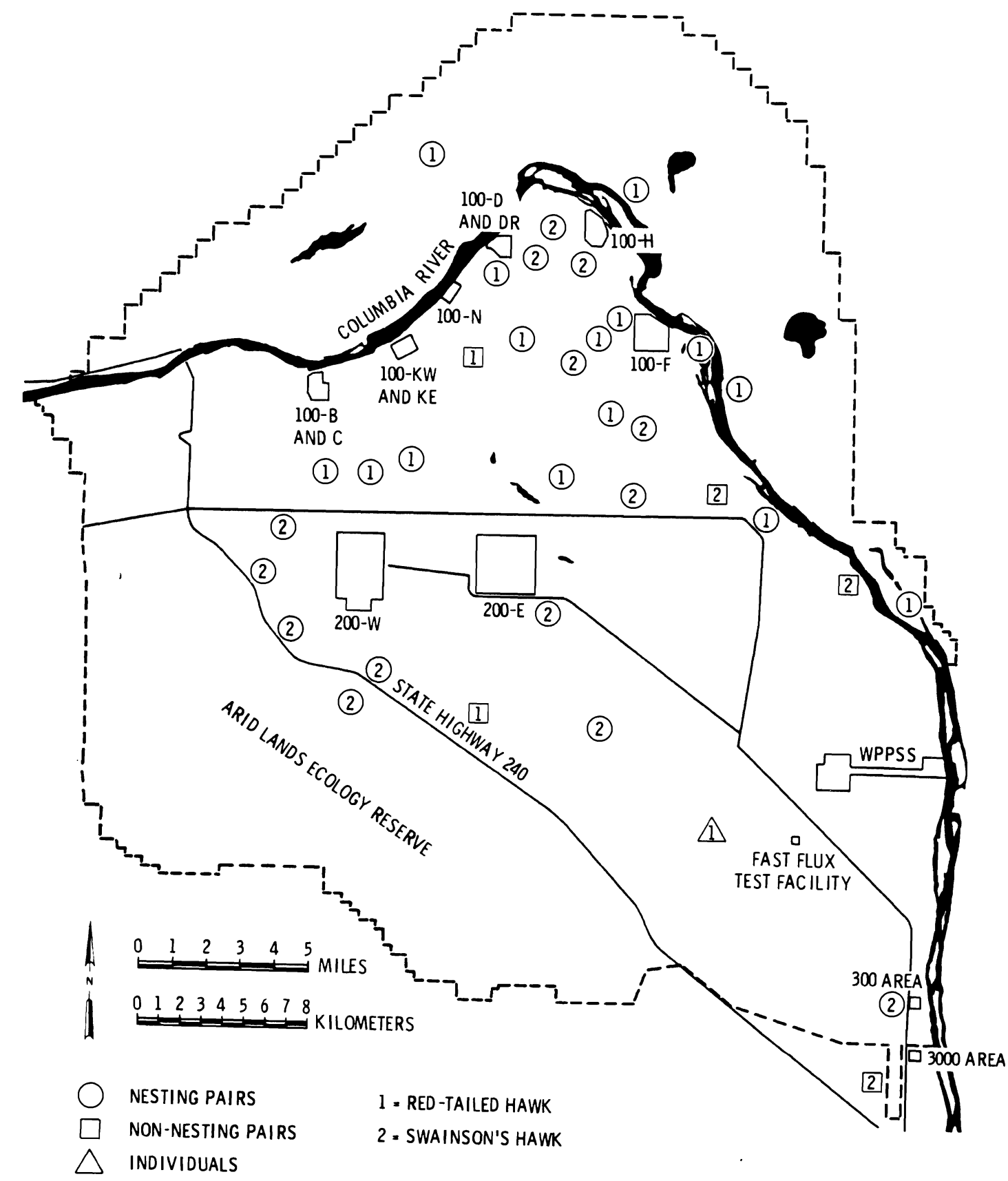

FIGURE 9. Locations of Nesting and Non-nesting Pairs and Single Red-tailed and Swainson's Hawks - 1976 


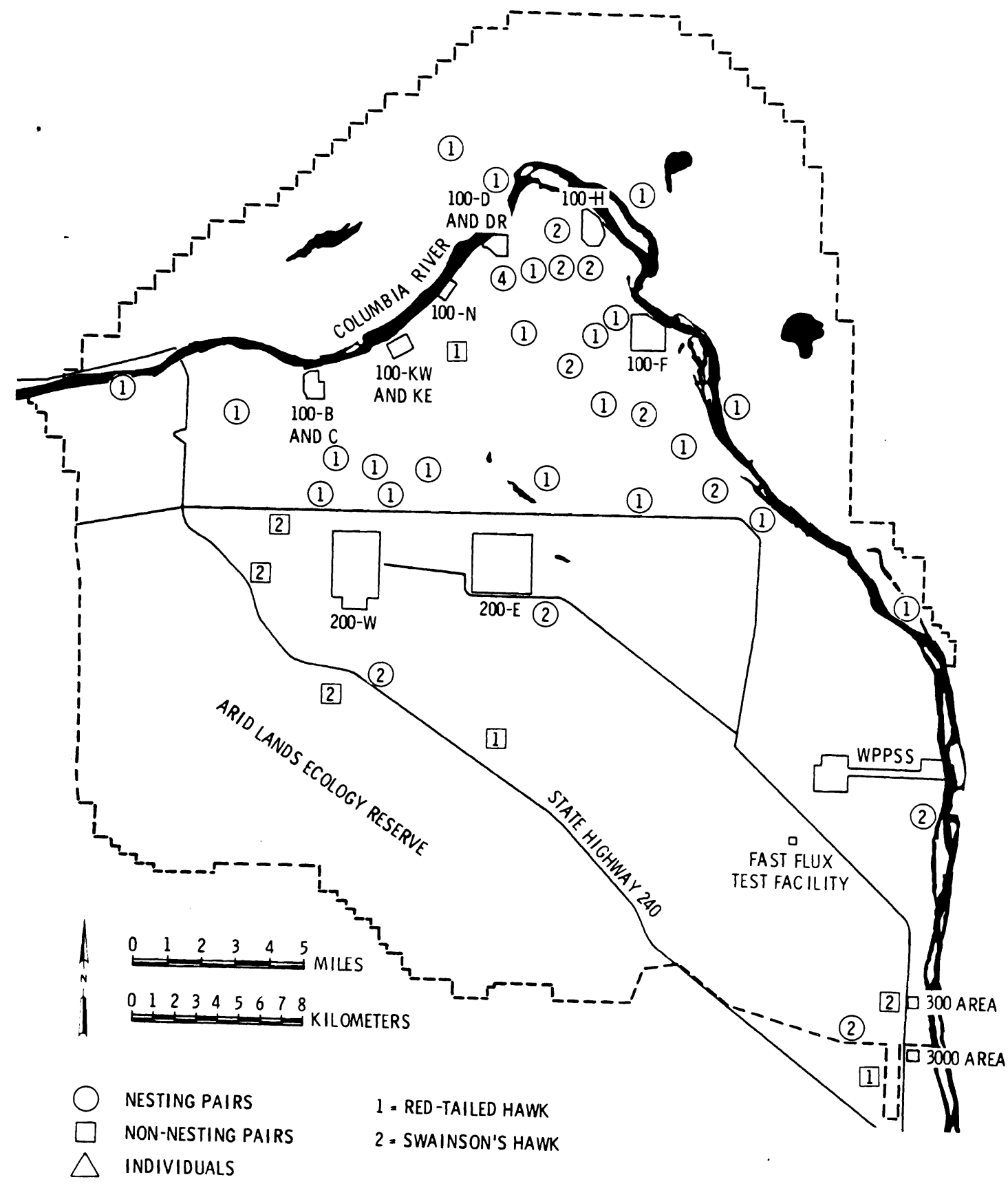

FIGURE 10. Locations of Nesting and Non-nesting Pairs and Single Red-tailed and Swainson's Hawks - 1977 


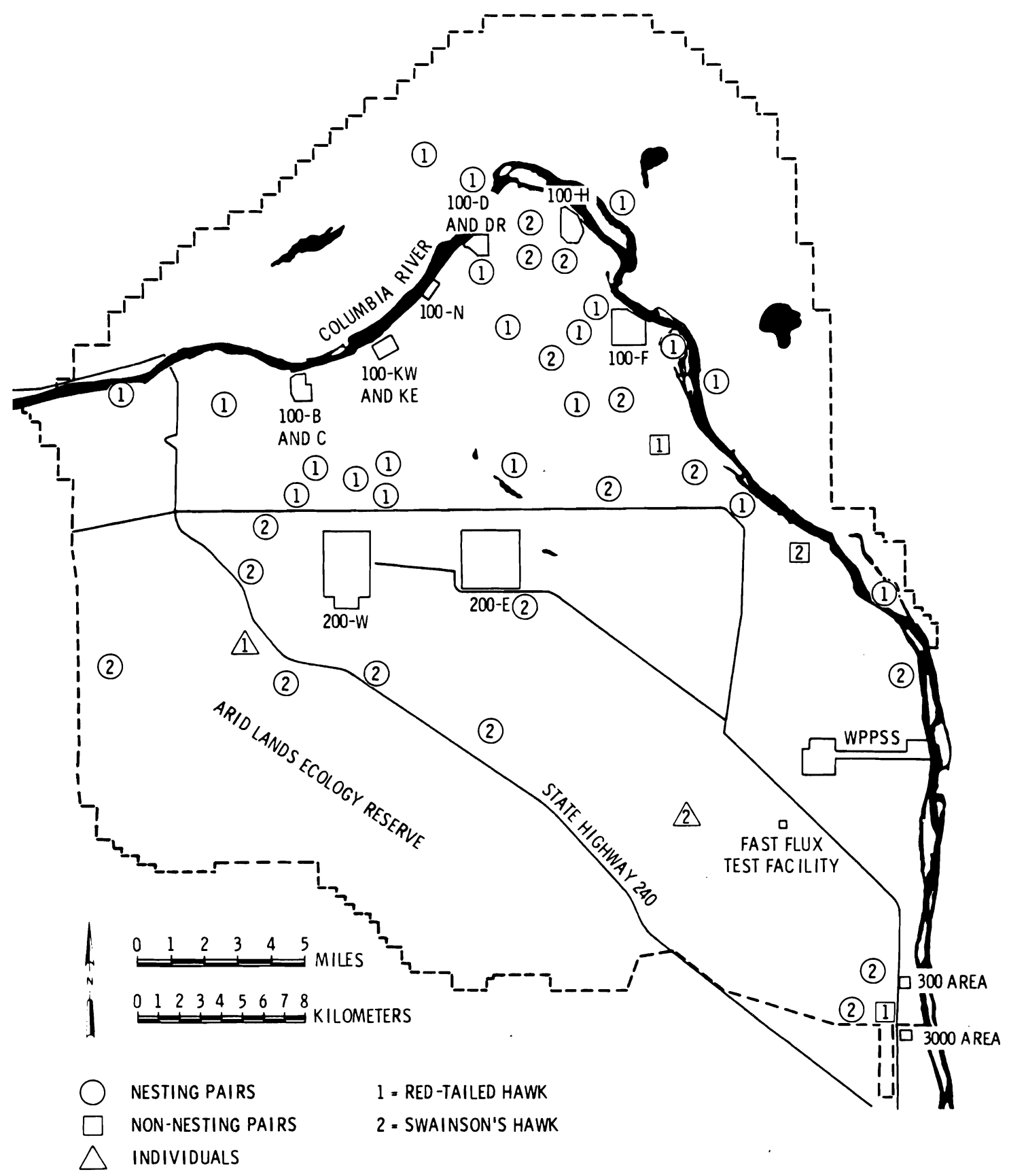

FIGURE 11. Locations of Nesting and Non-nesting Pairs and
Single Red-tailed and Swainson's Hawks - 1978 


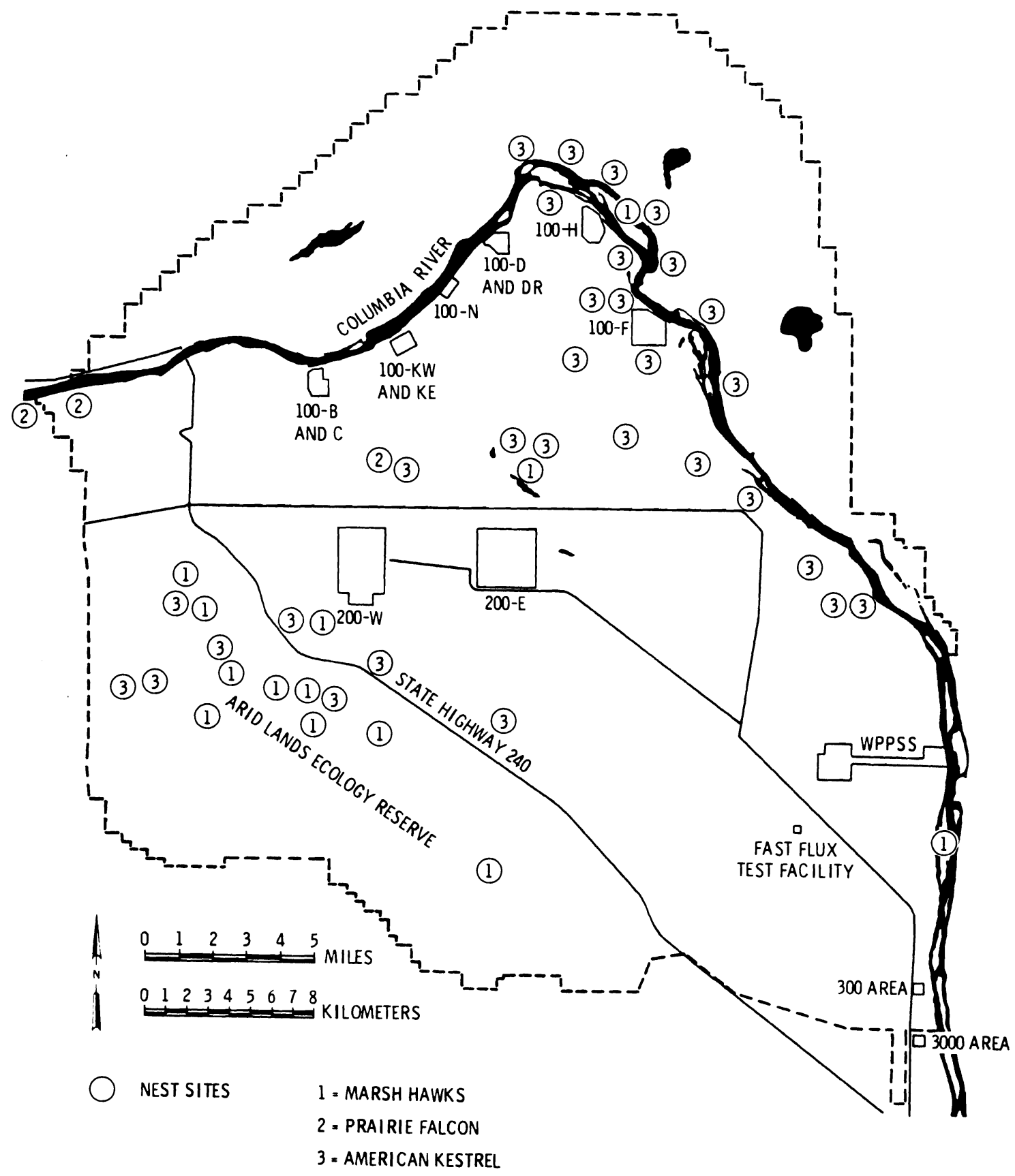

* NOT ALL NEST SITES USED IN ANY ONE YEAR.

FIGURE 12. Nesting Sites used by Marsh Hawks, Prairie Falcons, and American Kestrels from 1975-1978. 
TABLE 12. Number of Individual Adult Raptors Living on the Hanford Site during the 1975 through 1978 Nesting Seasons

\begin{tabular}{|c|c|c|c|c|}
\hline Species & 1975 & 1976 & 1977 & 1978 \\
\hline Great Horned ow 1 & 16 & 19 & 15 & 11 \\
\hline Long-eared ow 1 & 13 & 18 & 17 & 18 \\
\hline Short-eared owl & 4 & 5 & 4 & 4 \\
\hline Barn ow 1 & 8 & 9 & 5 & 4 \\
\hline Burrowing owl & 52 & 40 & 50 & 44 \\
\hline Marsh hawk & 10 & 10 & 10 & 10 \\
\hline Red-tailed hawk & 19 & 35 & 50 & 45 \\
\hline Swains on's hawk & 35 & 32 & 30 & 37 \\
\hline Prairie falcon & 4 & 4 & 4 & 6 \\
\hline American kestrel & 20 & 20 & 20 & 20 \\
\hline Total Raptors & 181 & 192 & 205 & 199 \\
\hline $\begin{array}{l}\text { Total Estimated Biomass } \\
\text { in kilograms }\end{array}$ & 107.39 & 127.38 & 135.32 & 130.90 \\
\hline Biomass $\left(\mathrm{kg} / \mathrm{km}^{2}\right)$ & 0.073 & 0.086 & 0.092 & 0.089 \\
\hline $\begin{array}{l}\text { Population Densities } \\
\text { Individual } 1 \mathrm{~s} / \mathrm{km}^{2}\end{array}$ & 0.120 & 0.130 & 0.140 & 0.135 \\
\hline
\end{tabular}

pairs, but the ultimate factor of nest destruction would have masked their importance.

The minimum and maximum sizes of the total raptor breeding population varied from a low of 181 individuals in 1975 to a maximum of 205 in 1977 (Table 12). The number of individuals recorded each year was fairly constant for most species, however. Great-horned and barn owl populations decreased as red-tailed hawk numbers increased. Population data for burrowing owls, marsh 
hawks and American kestrels should be taken to represent the minimum populations sizes for these species because their nests are inherently difficult to find. The population estimates for burrowing owls indicate then that this species is certainly the most abundant nesting raptor to use the Hanford Site. Three species, great horned owls and red-tailed and Swainson's hawk comprised over $40 \%$ of the average yearly raptor population. Of these, the Swainson's hawk annually contributed over $15 \%$ to the total breeding population. Redtailed hawks constituted about 10\% of the total population in 1975 but increased to $24 \%$ of the population in 1977 .

The short-eared and barn owls and prairie falcon were the least abundant of all nesting raptors. Short-eared owls were found nesting only around Benson Ranch ( $\mathrm{Figures} 4$ through 7 ) using a habitat dominated by Jim-Hill Mustard (Sisymbrium altissium) and cheatgrass. The deep sandy-loam soils in this area received underground percolation of water from Rattlesnake Springs and supported a dense-tall growth of plants. The mustards in this area of ten exceeded $1 \mathrm{~m}$ in height while cheatgrass of ten approached $0.5 \mathrm{~m}$.

The densities of adult nesting raptors from year to year averaged 0.13 birds per $\mathrm{km}^{2}$, ranging from a low of 0.12 in 1975 to 0.14 in 1978 (Table 12). When expressed as biomass $\left(\mathrm{kg} / \mathrm{km}^{2}\right)$, a $1 \mathrm{ow}$ of $0.073 \mathrm{~kg}$ of adult raptors were present in the nesting season of 1975 and $0.092 \mathrm{~kg}$ in 1977 with an average of $0.085 \mathrm{~kg}$. Weights used for calculating biomass of raptors are given in Table 13.

TABLE 13. Body Weights of Raptors Nesting on the Hanford Site and Consumption Rates

\begin{tabular}{lcc}
\hline \multicolumn{1}{c}{ Species } & $\begin{array}{c}\text { Average Body Weight } \\
(\mathrm{g}) \text { a }\end{array}$ & $\begin{array}{c}\text { Mean Daily Consumption } \\
\text { rate }(\mathrm{g}) \text { b }\end{array}$ \\
\hline Great Horned ow1 & 1505 & 84 \\
Long-eared ow7 & 295 & 38 \\
Short-eared ow1 & 346 & 78 \\
Barn owl & 466 & 26 \\
Burrowing ow1 & 170 & 100 \\
Marsh hawk & 521 & 109 \\
Red-tailed hawk & 1126 & 100 \\
Swainson's hawk & 988 & 112 \\
Prairie falcon & 709 & 20 \\
American kestrel & 114 &
\end{tabular}

aWeights represent the average for males and females combined and have been taken from the following sources: 0lendorff 1971, 01endorff 1973a, Marti 1974, Earhart and Johns on 1970, Craighead and Craighead 1956, Thomsen 1971, and Endersen 1964.

bFrom Johnson 1978. Data represent consumption rate of captive raptors. 
Production of young raptors and biomass are presented in Table 14 . For the purpose of this report, fledged young weights are assumed to be nearly equal to adult weights. Johnson (1978) stated that in some species, fledged young weigh less than adults (short-eared owls) in others they weight more (male red-tailed hawks and perhaps falcons), while in others weight of fledglings can be similar to adults (great horned owls). Since all raptor species are pooled in order to present a picture of total biomass on the Hanford Site, then these estimates of biomass production are likely to be relatively close if fledglings are assumed to be similar in weight to adults.

The combined biomass of fledged young and breeding and non-breeding adults present on the Hanford Site each breeding season from 1975 through 1978 are presented in Table 15. Biomass varied from a 1 ow of $145 \mathrm{~g} / \mathrm{km}^{2}$ in 1975 to a high of $177 \mathrm{~g} / \mathrm{km}^{2}$ in 1977 . This represents a $10 \%$ increase in total biomass. The biomass of young produced in relation to biomass of adults present dropped by $2 \%$, however, over the same time period and dropped by $4 \%$ in 1978 . The

TABLE 14. Number of Young Raptors Produced Each Year (1975 through 1978) on the Hanford Site

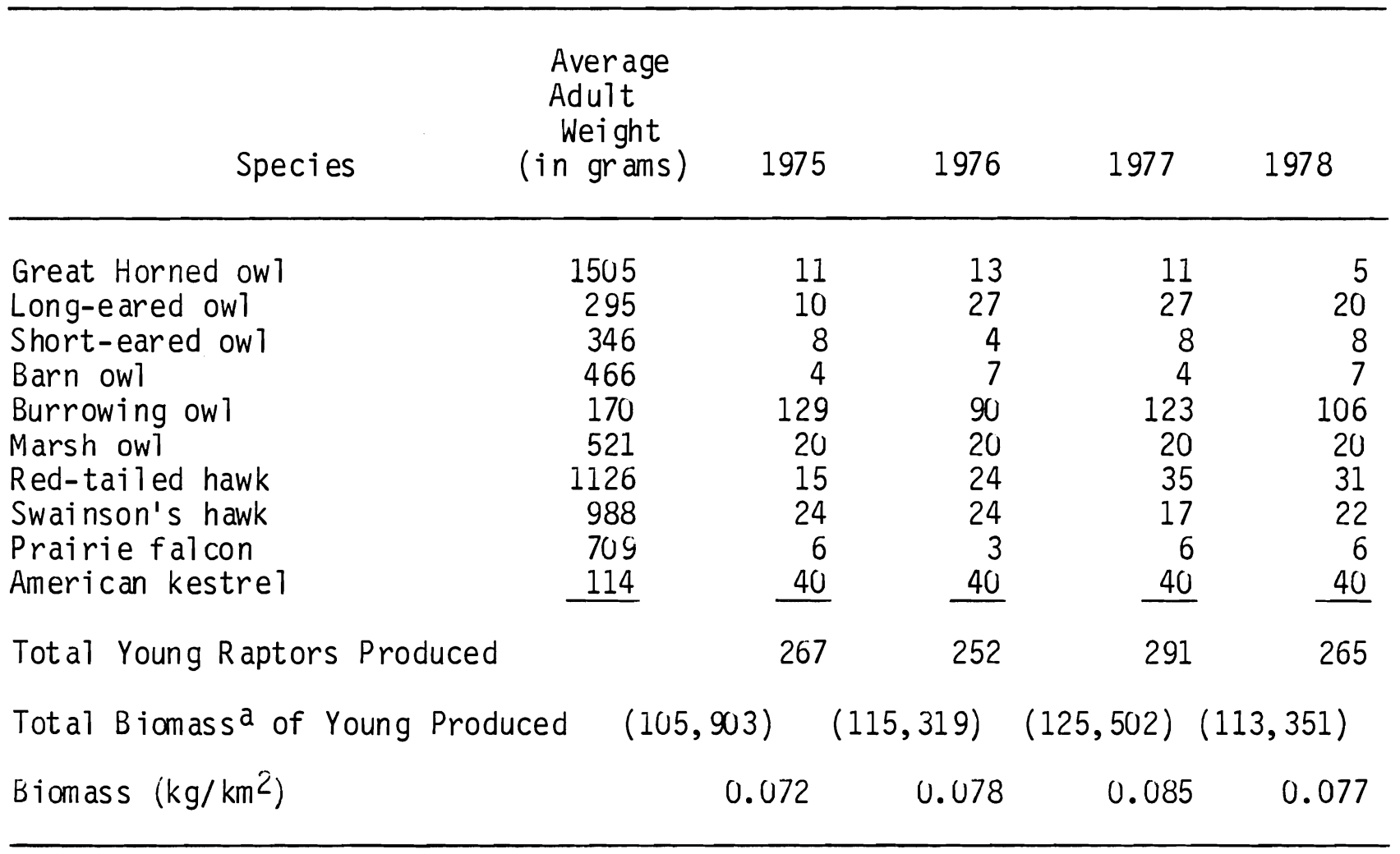

aBiomass of fledged raptors was calculated by using average adult weights. 
TABLE 15. Productivity of Raptorial Birds on the Hanford Site--1975 through 1978.

\begin{tabular}{cccc}
\hline Year & $\begin{array}{c}\text { Biomass of young } \\
\text { after fledging } \\
\left(\mathrm{kg} / \mathrm{km}^{2}\right)\end{array}$ & $\begin{array}{c}\text { Biomass of adults } \\
\left(\mathrm{kg} / \mathrm{km}^{2}\right)\end{array}$ & $\begin{array}{c}\text { Biomass of adult and } \\
\text { young af ter fledging } \\
\left(\mathrm{kg}_{\mathrm{km}}{ }^{2}\right)\end{array}$ \\
\hline 1975 & 72 & 73 & 145 \\
1976 & 78 & 86 & 164 \\
1977 & 85 & 92 & 177 \\
1978 & 77 & 89 & 166 \\
\hline
\end{tabular}

decrease in biomass of young produced per biomass of adults present is a sensitive indication of reproductive performance (0lendorff 1973a) only if sampling procedures are consistent or the same numbers of the same species are considered.

0lendorff (1973b) studied the ecology of nesting birds of prey in Colorado, and provided data on productivity of 1 arge birds of prey. He found that $252.8 \mathrm{~g}$ of adults and fledged young were present per kilometer on his $2,598 \mathrm{~km}^{2}$ study area. The presence of ferruginous hawks and golden eagles in 01 lendorff's area may explain the differences in biomass between the Colorado and Hanford study sites.

In viewing energy flow in an ecosystem, the total biomass of adults and young is a measure of carrying capacity and trophic level importance of raptors. During the time frame of this study, the 1 ow of $145 \mathrm{~g} / \mathrm{km}^{2}$ in 1975 represents a low end of the raptor-carrying capacity while $177 \mathrm{~g} / \mathrm{km}^{2}$ represents a high. This high value resulted from a dramatic increase in red-tailed hawks due to an exploitation of habitats previously unavailable. In this situation, as noted earlier, utility pole nesting had been restricted by a utility company and when the restriction was lifted, red-tailed hawks moved in to use the utility poles as nest sites. Nest sites were clearly a limiting factor for red-tailed hawks. Olendorff (1973a) felt this to be the case on much of the Hanford Site and indicated that by providing nest sites in areas devoid of them, one could substantially increase the total raptor population on the Hanford Site. Even though prey were available for raptors throughout the Hanford environs, raptors were not using the resource because nest sites were not available. Only ground-nesting raptors were able to exploit the prey. The restriction of red-tailed hawks from nesting on utility poles limited their population in that area. This was proof that prey was not the ultimate limiting factor for a population of predatory birds. In the case of raptors, availability of nest sites appears to be of major importance. 
SEASONAL USE OF THE HANFORD SITE BY RAPTORS

\section{THE BREEDING POPULATION}

Many of the birds of prey that nest on the Hanford Site remain in the area throughout the year. The great-horned owl, long-eared owl, barn owl, short-eared owl, red-tailed hawk, American kestrel and marsh hawk are the so-called "permanent" residents. The owls are probably the true permanent residents with the hawks displaying an exchange between breeding birds and wintering birds. The hawks also appear to have different wintering and breeding territories.

The breeding raptors which are not permanent residents are the Swainson's hawk, ferruginous hawk, and burrowing ow1. The Swainson's hawk arrives on the Hanford Site in early April, and leaves by mid-September. This species migrates mostly to Argentina (Fitzner 1980). The ferruginous hawk is present in the Columbia Basin from late February through October, preferring more southerly latitudes of the United States for its winter home. Burrowing owls behave similar to ferruginous hawks, except that they arrive in March. A few birds are present in the Columbia Basin during most winters. During the winter of 1978, several pairs of burrowing owls were observed near Benton City and Mattawa.

\section{THE NON-BREEDING POPULATION}

The migrant and visiting raptors to the Hanford Site and the Columbia Basin include the turkey vulture, goshawk, Cooper's hawk, sharp-shinned hawk, rough-legged hawk, golden and bald eagles, osprey, gyrfalcon, peregrine falcon, pigeon hawk, screech owl, flammulated ow1, snowy owl, and saw-whet owl. An aerial transect was flown nine times during the fall and winter of 1976. The flight followed nearly 200 miles of the power line rights-of-ways that traversed the Hanford site. It provided a list (Table 16) of some of the raptor species encountered during the non-breeding season. The rough-legged hawk, eagles, and osprey are regular winter visitors and the golden eagle breeds in some areas of the basin. The rough-legged hawk breeds to the north and many spend the winter in the Columbia Basin. This species may effectively be occupying the Swainson's hawk niche during the winter. Some of the prey and habitat resources used by breeding Swainson's hawks may be used by rough-legged hawks in winter. The bald eagle and osprey are most abundant on the Hanford Site in the winter when spawning salmon and suckers are abundant. Golden eagles and bald eagles also are attracted to the Hanford Site by the availability of lagomorphs and wintering waterfowl.

From the above discussion, one can visualize the Columbia Basin and Hanford raptor community changing with the seasons. Certain species breed here, others migrate through while still others winter here. Some of the same individuals and species that nest in the Columbia Basin may also winter in the area, but this is uncertain at present. The raptor community is in a dynamic 
TABLE 16. Raptors Counted on a Fall and Winter Aerial Survey - 1976

Sept 17 Oct 8 Oct 23 Nov 25 Dec 9 Jan 2 Jun 30 Feb 20 Mar 8

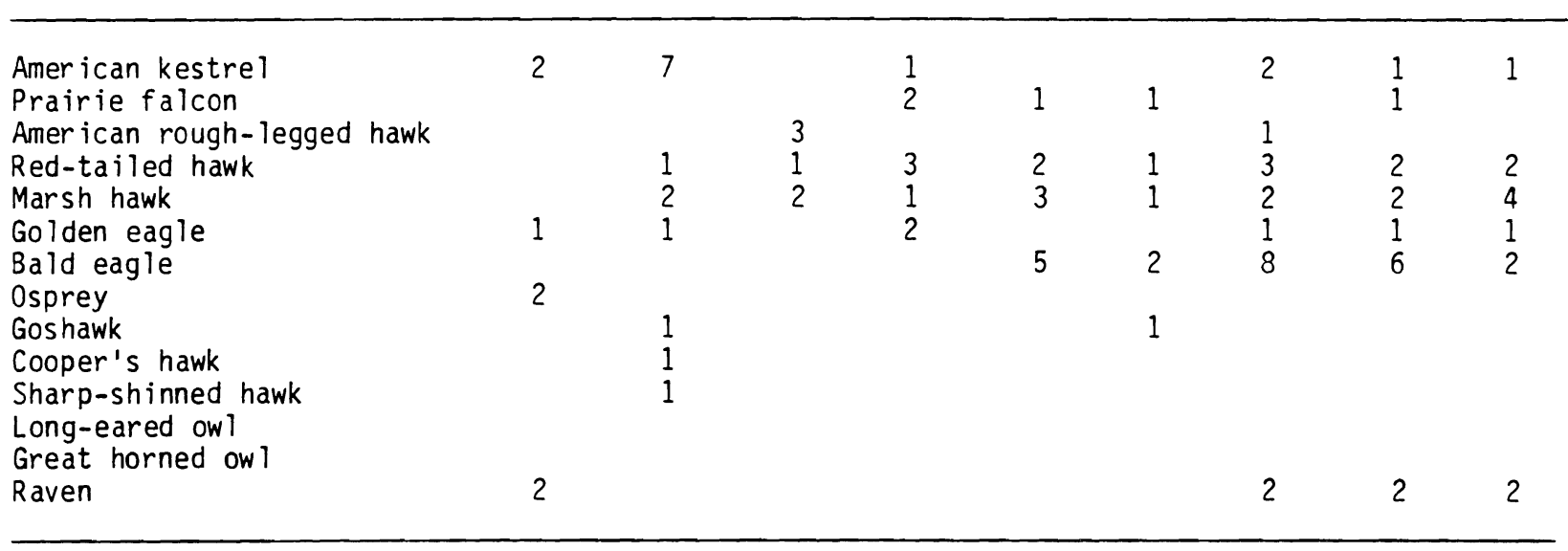

state, changing species composition and density with the seasons. These changes are dictated by factors such as prey availability, habitat, nest site availability, human disturbances, and weather.

\section{THE BREEDING CHRONOLOGY OF RAPTORS ON THE HANFORD SITE}

The reproductive chronologies of the five owl species and five hawk species are presented in Tables 17 and 18 respectively. The great horned ow had the earliest average laying date of 15 March, with the red-tailed hawk being the next earliest egg layer, averaging 10 April. Marsh hawks were similar to red-tailed hawks having an average laying date of 11 April. The burrowing owl, Swainson's hawk and American kestrel had average laying dates of 1 May, 12 May and 25 May, respectively. Long-eared owls and prairie falcons both had average laying dates of 21 Apri1.

The breeding season for the raptor population spans nearly six months with the great horned owl being the earliest nester and the American kestrel being the latest. Most of the raptor species that breed on the Hanford Site begin egg laying some time during mid-April to mid-May. The Swainson's hawk and American kestrel lay eggs nearly one month later than the other raptors.

The breeding season of raptors in the Columbia Basin is timed in such a way so that each raptor species can take full advantage of prey resources. Most of the breeding owl species rely heavily on rodents, particularly the Great Basin pocket mouse as a food source. Their breeding cycle overlaps the period of high rodent biomass (0'Farrel et a1. 1975). The diurnal raptors all tend to nest when there is an abundant supply of diurnal prey organisms. Passerine birds are fledging young, snakes and lizards are active, insects are abundant and lagomorphs are rearing young during the same period that young hawks are in need of food. 


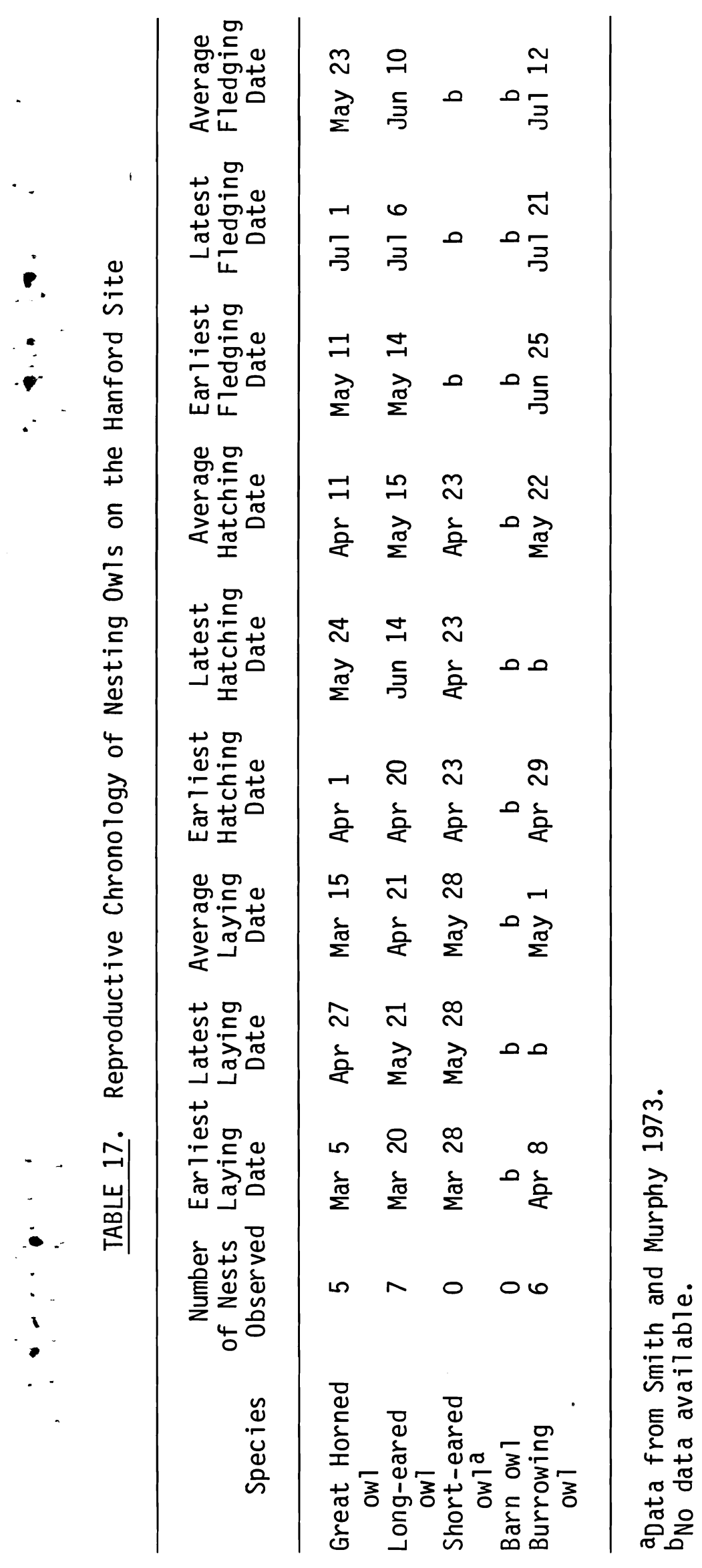

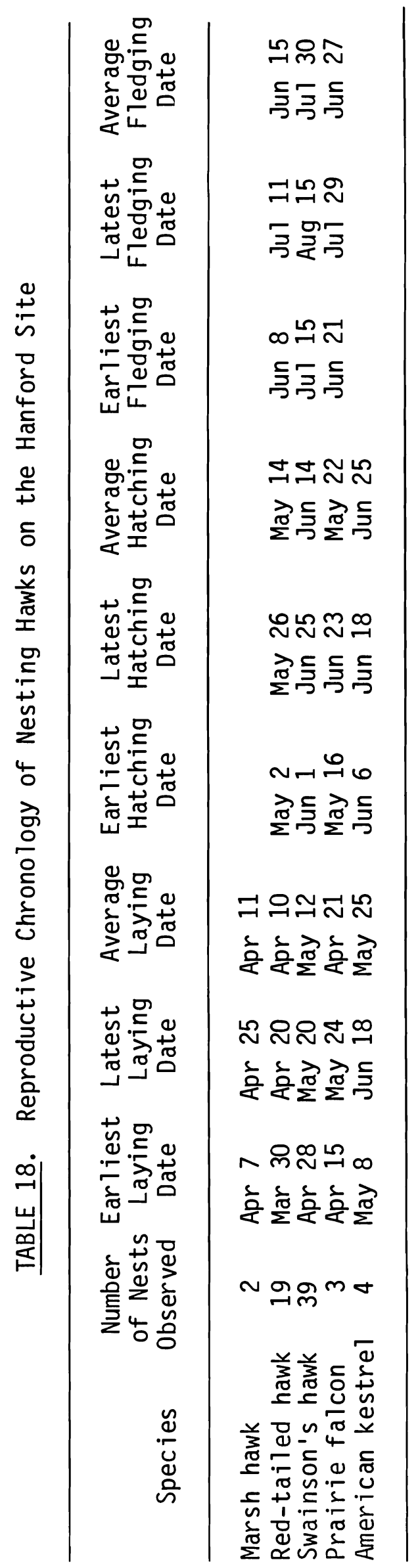




\section{FOOD OF THE STRIGIFORMES AND FALCONIFORMES}

The diets of the owls and hawks studied on the Hanford Site since 1973 are given in Tables 19 through 26. Of the ten raptor species found nesting on the Hanford Site, only the short-eared owl and marsh hawk diets were not determined during this study. Extensive data exist on the great-horned, (Table 19) long-eared (Table 20), burrowing owls (Table 21) and barn owls (Table 23) and for red-tailed (Table 22) and Swainson's hawks (Tables 24-25). The American kestrel and prairie falcon dietary data (Table 26), are scanty since the nests of these species were often inaccessible.

The raptor diets reveal that the burrowing owl ate the greatest diversity of species and was mainly an insectivore. Great horned owls, long-eared owls and barn owls were primarily small mammal consumers with great horned owls being more diverse in prey selection than the long-eared or barn owls. Redtailed hawks ate small mammals, lagomorphs, birds, and snakes in similar frequency, while Swainson's hawks tended to consume more snakes. Both had diets of similar species composition, except for this feature.

The diet of each raptor species is dictated by several factors. Of major importance are the physical prey catching capabilities of each species. Small raptors like kestrels and burrowing owls cannot, for instance, catch large lagomorphs and their diet reflects this. The large Buteos (Swainson's and redtailed hawk) and great-horned owl are quite capable of catching lagomorphs, ground squirrels, snakes and other large prey and their diet also reflects this fact. Olendorff (1973b) and Marti (1974) both have shown direct relationships between the size of the raptor and the size of the prey organisms they feed on. Our data substantiates these findings. 0lendorff (1973a) states that small raptors are more diverse in the numbers of prey species they consume since there are more small prey species available to prey on. The diet of the burrowing owl when compared with the larger great horned owl certainly verifies this.

An important consideration in a study of raptor predation is how much prey biomass are the raptors removing per unit area. During the breeding season, the adults raise their young and together the parents and offspring consume a given quantity of food per bird. The prey organisms they consume represent an energy and chemical transfer which when known can be used in studies of trophic level interactions and transfer coefficients for various environmental contaminants including radionuclides.

In determining the quantity of food the adult cohort and young cohort of the raptor population remove from the Hanford Site, we need to know a number of different parameters. These include:

1. Total number of birds present. 
TABLE 19. Food of Great Horned OWls on the Hanford DOE Site of Southcentral Washington

\begin{tabular}{|c|c|c|c|}
\hline Prey Species & Scientific Name & $\begin{array}{l}\text { Number } \\
\text { of items }\end{array}$ & $\begin{array}{l}\text { Percent of } \\
\text { Total Items }\end{array}$ \\
\hline $\begin{array}{l}\text { Small Mammals } \\
\text { Great Basin pocket mouse } \\
\text { Deer mouse } \\
\text { Montane meadow mouse } \\
\text { Northern pocket gopher } \\
\text { Sagebrush vole } \\
\text { Busy-tailed woodrat } \\
\text { Silvery-haired bat }\end{array}$ & $\begin{array}{l}\text { (Perognathus } \frac{\text { parvus }}{\text { (Peromyscus }} \text { manicuTatus) } \\
\left(\frac{\text { Picrotus }}{\text { Pentanus }}\right) \\
\frac{\text { Thomomys }}{\text { Lagurus }} \frac{\text { talpoides }}{\text { curtatus }} \\
\frac{\text { Neotoma }}{\text { Lasionyc }} \text { cinerea } \\
\text { teris noctivagans }\end{array}$ & $\begin{array}{r}251 \\
68 \\
17 \\
13 \\
8 \\
3 \\
1\end{array}$ & $\begin{array}{r}53.0 \\
14.4 \\
3.6 \\
2.7 \\
1.7 \\
0.6 \\
0.2\end{array}$ \\
\hline $\begin{array}{l}\text { Lagomorphs } \\
\text { Black-tailed jackrabbit } \\
\text { Nuttall's cottontail }\end{array}$ & $\frac{\text { Lepus }}{\text { Sylvilalifornicus }}$ cas nutta11ii & $\begin{array}{l}10 \\
12\end{array}$ & $\begin{array}{l}2.1 \\
2.5\end{array}$ \\
\hline $\begin{array}{l}\text { Birds } \\
\text { Rock dove } \\
\text { Mallard } \\
\text { American coot } \\
\text { California quail } \\
\text { Long-billed curlew } \\
\text { Starling } \\
\text { Black-billed magpie } \\
\text { Common flicker } \\
\text { Western burrowing owl } \\
\text { Ring-billed gull } \\
\text { Eared grebe }\end{array}$ & 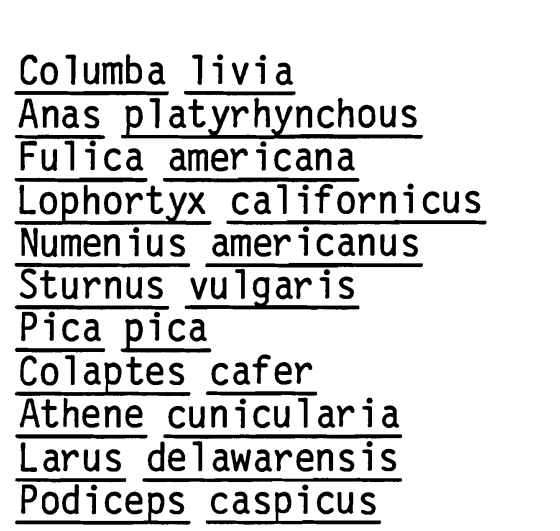 & $\begin{array}{l}7 \\
5 \\
5 \\
4 \\
2 \\
2 \\
2 \\
1 \\
1 \\
1 \\
1\end{array}$ & $\begin{array}{l}1.5 \\
1.0 \\
1.0 \\
0.8 \\
0.4 \\
0.4 \\
0.4 \\
0.2 \\
0.2 \\
0.2 \\
0.2\end{array}$ \\
\hline $\begin{array}{l}\text { Reptiles and Amphibians } \\
\text { Western yellow-bellied } \\
\text { racer } \\
\text { Bullsnake }\end{array}$ & 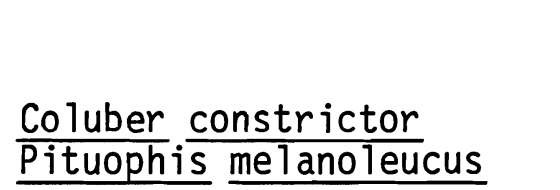 & $\begin{array}{l}2 \\
1\end{array}$ & $\begin{array}{l}0.4 \\
0.2\end{array}$ \\
\hline $\begin{array}{l}\text { Invertebrates } \\
\text { Scarab beet le } \\
\text { Tenebrionid beetle } \\
\text { Tettigoniidae grasshopper } \\
\text { Scorpion } \\
\text { Crawfish }\end{array}$ & $\begin{array}{l}\text { Paracotalpa granicollis } \\
\text { Contiotis setosa } \\
\frac{\text { Apote notabilis }}{\text { Paruroctonus boreus }} \\
\text { Pacifasticus } \\
\text { leniusculus }\end{array}$ & $\begin{array}{r}14 \\
2 \\
5 \\
4 \\
2\end{array}$ & $\begin{array}{l}3.0 \\
0.4 \\
1.0 \\
0.8 \\
0.4\end{array}$ \\
\hline $\begin{array}{l}\text { Unident ified } \\
\text { Small mammal } \\
\text { Lagomorphs } \\
\text { Birds }\end{array}$ & & $\begin{array}{l}3 \\
6 \\
3\end{array}$ & $\begin{array}{l}0.6 \\
1.2 \\
0.6\end{array}$ \\
\hline
\end{tabular}


TABLE 20. Food of Long-eared OWls in the Shrub-steppe of Southcentral Washington

\begin{tabular}{|c|c|c|c|}
\hline Prey Species & Scientific Name & $\begin{array}{l}\text { lumber } \\
\text { items }\end{array}$ & $\begin{array}{l}\text { Percent of } \\
\text { Total I tems }\end{array}$ \\
\hline \multicolumn{4}{|l|}{ Small Marmals } \\
\hline $\begin{array}{l}\text { Great Basin pocket mouse } \\
\text { Deer mouse } \\
\text { Montane meadow mouse } \\
\text { Sagebrush vole } \\
\text { Northern pocket gopher } \\
\text { Northern grasshopper }\end{array}$ & 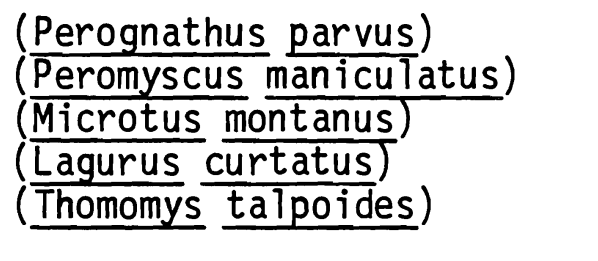 & $\begin{array}{r}514 \\
36 \\
7 \\
6 \\
5\end{array}$ & $\begin{array}{r}87.0 \\
6.1 \\
1.2 \\
1.0 \\
0.8\end{array}$ \\
\hline $\begin{array}{l}\text { mouse } \\
\text { Western harvest mouse } \\
\text { Merriam's shrew }\end{array}$ & $\begin{array}{l}\left.\frac{(\text { Onochomys }}{\text { (Reithrodontomys }} \frac{\text { leugaster })}{\text { Regalotis }}\right) \\
\text { (Sorex merriami) }\end{array}$ & $\begin{array}{l}2 \\
1 \\
3\end{array}$ & $\begin{array}{l}0.3 \\
0.2 \\
0.5\end{array}$ \\
\hline $\begin{array}{l}\text { Lagomorphs } \\
\text { Black-tailed jackrabbit } \\
\text { Nuttall's cottontail }\end{array}$ & $\left(\frac{\text { (Lepus }}{\text { (Sylvillalifornicus) }}\right.$ & $\begin{array}{l}2 \\
2\end{array}$ & $\begin{array}{l}0.3 \\
0.3\end{array}$ \\
\hline $\begin{array}{l}\text { Birds } \\
\text { Sage sparrow } \\
\text { Western meadowlark } \\
\text { Starling } \\
\text { Chukar }\end{array}$ & $\begin{array}{l}(\text { Amphispiza belli) } \\
\left(\frac{\text { Sturnella }}{\text { neglecta }}\right) \\
\left(\underline{\text { Sturnus }} \frac{\text { vulgaris }}{\text { Alectoris graeca }}\right)\end{array}$ & $\begin{array}{l}3 \\
3 \\
1 \\
1\end{array}$ & $\begin{array}{l}0.5 \\
0.5 \\
0.2 \\
0.2\end{array}$ \\
\hline \multirow{2}{*}{$\begin{array}{l}\text { Invertebrates } \\
\text { Scarab beet le } \\
\text { Tettigoniid } \\
\text { grasshopper } \\
\text { Crawfish }\end{array}$} & (Paracotalpa granicollis) & 1 & 0.2 \\
\hline & $\begin{array}{l}\text { (Apote notabilis) } \\
(\underline{\text { Pacifasticus leniusculus }})\end{array}$ & $\frac{1}{1}$ & $\begin{array}{l}0.2 \\
0.2\end{array}$ \\
\hline \multicolumn{4}{|l|}{ Unident if ied } \\
\hline $\begin{array}{l}\text { Birds } \\
\text { Mammals }\end{array}$ & & $\begin{array}{l}1 \\
1\end{array}$ & $\begin{array}{l}0.2 \\
0.2\end{array}$ \\
\hline
\end{tabular}


TABLE 21. Food of Burrowing Ow1s in the Shrub-steppe of Southcentral Washington

\begin{tabular}{|c|c|c|}
\hline Prey Species & $\begin{array}{l}\text { Number of } \\
\text { Items }\end{array}$ & $\begin{array}{l}\text { Percent of } \\
\text { Total Items }\end{array}$ \\
\hline $\begin{array}{l}\text { Insects } \\
\text { Unknown } \\
\text { Coleoptera } \\
\text { Unknown } \\
\text { Carabidae } \\
\text { Unknown } \\
\frac{\text { Agonum }}{\text { Amara }} \frac{\text { jejunum }}{\text { species }} \\
\frac{\text { Calosoma }}{\text { Cyminais }} \frac{\text { luxatum }}{\text { brevipennis }} \\
\frac{\text { Cyminais }}{\text { Dlanipennis }} \\
\frac{\text { Dichierus }}{\text { Hapalus }} \text { sp. }\end{array}$ & $\begin{array}{r}37 \\
49 \\
197 \\
69 \\
1 \\
3 \\
5 \\
113\end{array}$ & $\begin{array}{l}0.73 \\
0.96 \\
3.88 \\
1.36 \\
0.02 \\
0.06 \\
0.10 \\
2.22\end{array}$ \\
\hline $\begin{array}{l}\text { Curculionidae } \\
\text { Elateridae } \\
\text { Meloidae } \\
\text { Scarabidae } \\
\text { Unknown } \\
\frac{\text { Aphodius }}{\text { Aphodius }} \frac{\text { distinctus }}{\text { granarius }} \\
\frac{\text { Bothynus }}{\text { Diplotaxus }} \frac{\text { gibbosus }}{\text { Denebrosus }} \\
\frac{\text { Onthophagus }}{\text { Paracotalpa }} \frac{\frac{\text { nuchicornus }}{\text { Pranicollus }}}{\frac{\text { Phyllophaga }}{\text { Pociata }}} \\
\frac{\text { Polyphyl1a }}{\text { species }}\end{array}$ & $\begin{array}{r}29 \\
2 \\
3 \\
159 \\
64 \\
9 \\
290 \\
132 \\
28\end{array}$ & $\begin{array}{l}0.57 \\
0.04 \\
0.06 \\
3.13 \\
1.26 \\
0.18 \\
5.71 \\
2.60 \\
0.55\end{array}$ \\
\hline $\begin{array}{l}\text { Silphidae } \\
\text { Unknown } \\
\text { Necrophorus merginatum }\end{array}$ & $\begin{array}{r}3 \\
223\end{array}$ & $\begin{array}{l}0.06 \\
4.39\end{array}$ \\
\hline $\begin{array}{l}\text { Tenebrion idae } \\
\text { Unknown } \\
\text { Blapstinus } \\
\frac{\text { Conisattus }}{\text { Coniontus }} \frac{\text { substriatus }}{\text { nelsoni }} \\
\frac{\text { sleosa }}{\text { Eleodes }} \\
\frac{\text { Eleodes }}{\text { Eleolata }} \\
\frac{\text { Eleodes }}{\text { hispilabris }} \\
\frac{\text { Eleodes }}{\text { Eusattus }} \frac{\text { noroverrucula }}{\text { muricattus }}\end{array}$ & $\begin{array}{r}3 \\
1 \\
1100 \\
54 \\
5 \\
6 \\
1 \\
41 \\
63\end{array}$ & $\begin{array}{r}0.06 \\
0.02 \\
21.65 \\
1.06 \\
0.10 \\
0.12 \\
0.02 \\
0.81 \\
1.23\end{array}$ \\
\hline $\begin{array}{l}\text { Diptera } \\
\text { Asilidae }\end{array}$ & 1 & 0.02 \\
\hline
\end{tabular}


TABLE 21. (contd)

\begin{tabular}{|c|c|c|}
\hline Prey Species & $\begin{array}{c}\text { Number of } \\
\text { Items }\end{array}$ & $\begin{array}{l}\text { Percent of } \\
\text { Total Items }\end{array}$ \\
\hline $\begin{array}{l}\text { Hemiptera } \\
\text { Unknown } \\
\text { Pentatomidae } \\
\text { Reduvi i dae }\end{array}$ & $\begin{array}{l}1 \\
4 \\
5\end{array}$ & $\begin{array}{l}0.02 \\
0.08 \\
0.10\end{array}$ \\
\hline $\begin{array}{l}\text { Hymenoptera } \\
\text { Unknown } \\
\text { Apidae } \\
\text { Formicidae } \\
\text { Unknown } \\
\text { Pogonomyrmex owyheii }\end{array}$ & $\begin{array}{r}31 \\
1 \\
75 \\
1\end{array}$ & $\begin{array}{l}0.61 \\
0.02 \\
1.48 \\
0.02\end{array}$ \\
\hline Ichneumon idae & 20 & 0.39 \\
\hline $\begin{array}{l}\text { Mutillidae } \\
\text { Unknown }\end{array}$ & 31 & 0.61 \\
\hline $\begin{array}{l}\text { Specidae } \\
\text { Tiphiidae }\end{array}$ & $\begin{array}{r}6 \\
25\end{array}$ & $\begin{array}{l}0.12 \\
0.49\end{array}$ \\
\hline $\begin{array}{l}\text { Neuroptera } \\
\text { Raphiidae } \\
\quad \text { Agulla bicolor }\end{array}$ & 1 & 0.02 \\
\hline 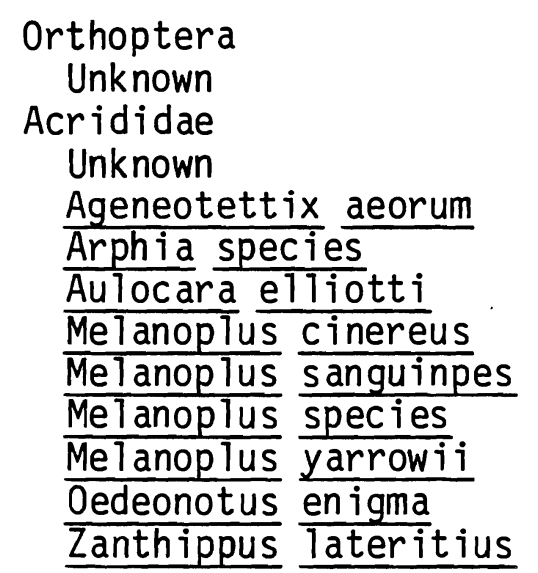 & $\begin{array}{r}19 \\
1 \\
1 \\
1 \\
5 \\
2 \\
2 \\
2 \\
5 \\
1\end{array}$ & $\begin{array}{l}0.37 \\
0.02 \\
0.02 \\
0.02 \\
0.10 \\
0.04 \\
0.04 \\
0.04 \\
0.10 \\
0.02\end{array}$ \\
\hline $\begin{array}{l}\text { Gryllacridae } \\
\text { Gryllidae } \\
\text { Tettigoniidae } \\
\text { Apote notabilis } \\
\text { Ceuthophilus vicinus } \\
\text { Eumu } \\
\text { Steiroxis species }\end{array}$ & $\begin{array}{r}441 \\
236 \\
3 \\
15\end{array}$ & $\begin{array}{l}8.68 \\
4.65 \\
0.06 \\
0.30\end{array}$ \\
\hline
\end{tabular}


TABLE 21. (contd)

\begin{tabular}{|c|c|c|}
\hline Prey Species & $\begin{array}{l}\text { Number of } \\
\text { Items }\end{array}$ & $\begin{array}{l}\text { Percent of } \\
\text { Total Items }\end{array}$ \\
\hline $\begin{array}{l}\text { Siphonaptera } \\
\text { Solpugida }\end{array}$ & $\begin{array}{r}1 \\
48\end{array}$ & $\begin{array}{l}0.02 \\
0.94\end{array}$ \\
\hline \multicolumn{3}{|l|}{ OTHER INVERTEBRATES } \\
\hline $\begin{array}{l}\text { Scorpion } \\
\text { Unknown Arthropod } \\
\text { Acarina } \\
\text { Araneida } \\
\text { Unknown } \\
\text { Ctenizidae }\end{array}$ & $\begin{array}{r}207 \\
2 \\
4 \\
11 \\
126\end{array}$ & $\begin{array}{l}4.07 \\
0.04 \\
0.08 \\
0.02 \\
2.48\end{array}$ \\
\hline REPTILES & 1 & 0.22 \\
\hline BIRDS & 2 & 0.04 \\
\hline \multicolumn{3}{|l|}{ MAMMALS } \\
\hline Insectivora & & \\
\hline $\begin{array}{l}\text { Soricidae } \\
\text { Sorex merriami }\end{array}$ & 1 & 0.02 \\
\hline $\begin{array}{l}\text { Rodentia } \\
\text { Cricetidae } \\
\text { Lagurus } \\
\text { Peromyscustatus } \\
\text { Reithrodontomys megalotis }\end{array}$ & $\begin{array}{r}69 \\
78 \\
2\end{array}$ & $\begin{array}{l}1.36 \\
1.54 \\
0.04\end{array}$ \\
\hline $\begin{array}{l}\text { Heteromyidae } \\
\text { Perograthus parvus }\end{array}$ & 526 & 10.35 \\
\hline $\begin{array}{l}\text { Geomyidae } \\
\text { Thomomys talpoides }\end{array}$ & 53 & 1.04 \\
\hline Unknown rodent & 101 & 1.99 \\
\hline $\begin{array}{l}\text { Lagomorpha } \\
\text { Unknown Marmal }\end{array}$ & $\begin{array}{r}3 \\
22\end{array}$ & $\begin{array}{l}0.06 \\
0.43\end{array}$ \\
\hline MISCELLANEOUS & 1 & 0.02 \\
\hline
\end{tabular}


TABLE 22. Food of Red-tailed Hawks in the Shrub-steppe of Southeastern Washington

Items

Prey Species

Scientific Name

Number of

Percent of .

Items Total

Small Mammals

Great Basin pocket mouse

Northern pocket gopher

Perognathus parvus

Thomomys talpoides

1

0.60

Townsend's ground squirrel

Spermophilus townsendi $i$

53

1.20

31.20

Lagomorphs

Black-tailed jackrabbit Nuttall cottontail

Lepus californicus

SyTvilagus nuttaT1ii

20

13

11.80

7.70

Birds

Western meadowlark

Mourning dove

Burrowing ow 1

Ring-necked pheasant

Chuck ar

Black-billed magpie

Rock dove

Sturnella neglecta

Zenaidura macrorura

Athene cunicularia

Phasianus colchicus

Alectoris graeca

Pica pica

Columba Tivia

0.6

0.6

0.6

Reptiles and Amphibians

Western yellow-bellied racer

Bullsnake

Western rattlesnake

Coluber constrictor

38

22.4

Pituophis melanoleucus

Crotalus viridis

21

12.4

1

0.6

Invertebrates

Tettigoniid grasshopper

Tenebrionid beetle

Apote notabilis

Eleodes sp

1

0.6

1

0.6

Unident if ied

Small marmals

Birds

2
2

1.2

1.2 


\section{TABLE 23. Food of Barn Owls Nesting in the Shrub-steppe of}

Southcentral Washington

\begin{tabular}{|c|c|c|c|}
\hline Prey Species & Scientific Name & $\begin{array}{l}\text { iber of } \\
\text { tems }\end{array}$ & $\begin{array}{l}\text { Percent of } \\
\text { Total Items }\end{array}$ \\
\hline \multicolumn{4}{|l|}{ Small Mammals } \\
\hline $\begin{array}{l}\text { Great Basin pocket mouse } \\
\text { Deer mouse } \\
\text { Montane meadow mouse } \\
\text { Northern pocket gopher } \\
\text { Bushy-tailed wood rat } \\
\text { Silvery-haired bat }\end{array}$ & 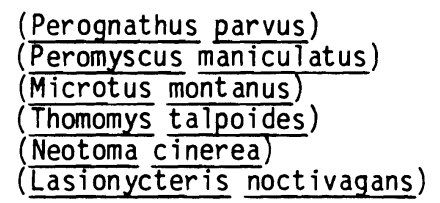 & $\begin{array}{r}175 \\
51 \\
4 \\
4 \\
2 \\
1\end{array}$ & $\begin{array}{r}68.6 \\
20.0 \\
1.6 \\
1.6 \\
0.8 \\
0.4\end{array}$ \\
\hline \multicolumn{4}{|l|}{ Lagomorphs } \\
\hline Nuttall's cottontail & (Sylvilagus nuttallii) & 9 & 3.5 \\
\hline \multicolumn{4}{|l|}{ Birds } \\
\hline $\begin{array}{l}\text { Rock dove } \\
\text { Western meadowl ark }\end{array}$ & $\left(\begin{array}{l}\text { (Columba } \\
(\underline{\text { Sturnel livia) }}) \\
\text { neglecta })\end{array}\right.$ & $\begin{array}{l}6 \\
1\end{array}$ & $\begin{array}{l}2.4 \\
0.4\end{array}$ \\
\hline
\end{tabular}

TABLE 24. Food Items of Swainson's Hawks on the Hanford Site (Prey Fed to Young Hawks by Parent Birds) - 1973-1976

\begin{tabular}{|c|c|c|c|}
\hline Prey Species & & No. & \% Frequency \\
\hline Mammals & & & 21.8 \\
\hline $\begin{array}{l}\text { Black-tailed jackrabbit } \\
\text { Nuttall's cottontail } \\
\text { Townsend's ground squirrel } \\
\text { Northern pocket gopher } \\
\text { Great Bas in pocket mouse } \\
\text { Unidentified small mammal }\end{array}$ & 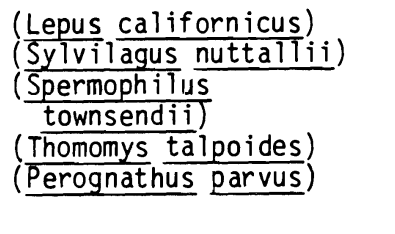 & $\begin{array}{r}11 \\
8 \\
8 \\
3 \\
5 \\
2\end{array}$ & $\begin{array}{l}6.5 \\
4.7 \\
4.7 \\
1.8 \\
2.9 \\
1.2\end{array}$ \\
\hline Birds & & & 14.6 \\
\hline $\begin{array}{l}\text { Magpie } \\
\text { Mallard } \\
\text { Meadowlark } \\
\text { Pheasant } \\
\text { Sage sparrow } \\
\text { Ring-billed gull } \\
\text { Long-billed curlew } \\
\text { Starling }\end{array}$ & 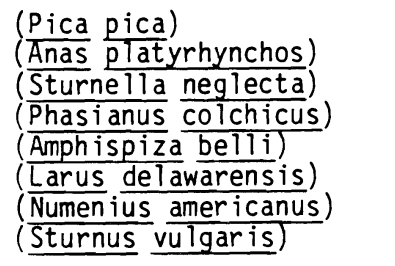 & $\begin{array}{l}4 \\
4 \\
5 \\
2 \\
2 \\
6 \\
1 \\
1\end{array}$ & $\begin{array}{l}2.4 \\
2.4 \\
2.9 \\
1.2 \\
1.2 \\
3.5 \\
0.5 \\
0.5\end{array}$ \\
\hline Reptiles and amphibiaris & & & $\underline{63.6}$ \\
\hline $\begin{array}{l}\text { Western yellow-bellied racer } \\
\text { Bullsnake } \\
\text { Striped whipsnake } \\
\text { Western toad }\end{array}$ & $\begin{array}{l}\left(\frac{\text { Coluber }}{\text { Pituoph }} \frac{\text { constrictor }}{\text { Pis }}\right) \\
(\text { Masticopholeucus }) \\
(\text { Bufo boreas })\end{array}$ & $\begin{array}{r}86 \\
18 \\
2 \\
2 \\
\end{array}$ & $\begin{array}{r}50.6 \\
10.6 \\
1.2 \\
1.2\end{array}$ \\
\hline & \multicolumn{3}{|c|}{$N=170$} \\
\hline
\end{tabular}


TABLE 25. Food Items of Swainson's Hawks on the Hanford Site During the Post-fledging Period

Prey Species
No.

$\%$ Frequency
Mammals

Townsend's ground squirrel

Northern pocket gopher

B lack-tailed jackrabbit

Great Basin pocket mouse

Deer mouse

Nuttall's cottontail

Unidentified small mammal
(Spermophilus

townsendii)

(Thomomys talpoides)

(Lepus cal ifornicus)

(Perognathus parvus)

(Peromyscus maniculatus)

(Sylvilacus nutta17ii)

$\underline{32.1}$

Birds

(Sturnella neglecta)

Meadow 1 ark

Ring-billed gull

Starling

Horned lark

(Larus de 1 awarensis)

(Sturnus vulgaris)

(Eremoph ila alpestris)

87

70

10

8

11

4
7

14.2

11.4

1.6

1.3

1.8

0.7

1.1

1.9

1.1

0.2

0.2

0.2

Reptiles and amphibians

Western yellow-bellied racer Bullsnake

(Coluber constrictor)

303

(Pituophis melanoleucus) 15

52.0

49.5

2.5

Insects

14.2

Orthoptera

Acrididae

Apote notabilis

31

38

5.1

Coleoptera

Paracatalpa granicola

Polyphylla sp.

Tenebrionidae

Elateridae

12

1

1

1

6.2

Unidentified insects

2.0

0.2

0.2

0.2

0.3 
TABLE 26. Food Items of Prairie Falcons and American Kestrels in the Shrub-steppe of Southcentral Washington

Prey Species

Number

Mammals

Bushy-tailed woodrat

Great Basin pocket mouse

Northern pocket gopher

Townsend's ground squirrel

Nuttall's cottontail

PRAIRIE FALCON

(Neotoma cinerea)

(Perognathus parvus)

(Thomomys talpoides)

(Spermophilus townsendii)

(Sylvilagus nuttal1ii)

1
4
7
1
8

Birds

Western meadow lark

Horned lark

(Sturnella neglecta)

(Eremophila alpestris)

AMERICAN KESTREL

Mammals

Great Basin pocket mouse

(Perognathus parvus)

1

Birds

Western meadow lark

Horned lark

Unidentified passerine

(Sturnella neglecta)

(Eremophi1a alpestris)

2
1
1

Reptiles

Short-horned lizard

Sagebrush lizard

(Phrynosoma douglassi)

(Sceloporus graciosus)

3
5

2. Energy requirements--grams of food needed to support a bird per unit of time.

3. Amount of time the bird spends on the Hanford Site.

The total amount of food consumed (TAFC) by the adult Swainson's hawk population would equal the number of adult birds (Table 27) present ( $A$ ) during a breeding season multiplied by the number of days present (D) on the Hanford Site, multiplied by the quantity of food (QF) needed to support one adult per day (Johnson 1978). In computing the total adult food consumption (TAFC) we 
TABLE 27. Biomass of Swainson's Hawks Produced on the Hanford Site

\begin{tabular}{|c|c|c|c|c|c|}
\hline $\begin{array}{l}\text { Biomass } \\
\text { Year } \\
\end{array}$ & $\begin{array}{l}\text { Number } \\
\text { Adults } \\
\end{array}$ & $\begin{array}{l}\text { Biomass } \\
\text { of Adults }(\mathrm{g})\end{array}$ & $\begin{array}{c}\text { Number of } \\
\text { Fledged Young } \\
\end{array}$ & $\begin{array}{c}\text { Biomass } \\
\text { Fledged young }(\mathrm{g}) \\
\end{array}$ & $\begin{array}{l}\text { Total } \\
\text { biomass }(\mathrm{g}) \\
\end{array}$ \\
\hline $\begin{array}{l}1975 \\
1976 \\
1977 \\
1978\end{array}$ & $\begin{array}{l}35 \\
32 \\
30 \\
37\end{array}$ & $\begin{array}{l}34580 \\
31616 \\
29640 \\
36556\end{array}$ & $\begin{array}{l}24 \\
24 \\
17 \\
22\end{array}$ & $\begin{array}{l}23712 \\
23712 \\
16796 \\
21736\end{array}$ & $\begin{array}{l}58292 \\
55328 \\
46436 \\
58292\end{array}$ \\
\hline
\end{tabular}

have assumed that the average adult spends 140 days on the Hanford Site. The Equation, $T A F C=A \times D \times Q F$ when supplied with data for 1975 through 1978 would yield the following:

$$
\begin{aligned}
& \text { TAFC } 1975=35 \times 140 \times 100 \mathrm{~g} / \text { day }=490 \mathrm{~kg} \\
& \text { TAFC } 1976=32 \times 140 \times 100 \mathrm{~g} / \text { day }=448 \mathrm{~kg} \\
& \text { TAFC } 1977=30 \times 140 \times 100 \mathrm{~g} / \text { day }=420 \mathrm{~kg} \\
& \text { TAFC } 1978=37 \times 140 \times 100 \mathrm{~g} / \text { day }=518 \mathrm{~kg}
\end{aligned}
$$

The total young food consumption (TYFC) can be determined by using the following data: biomass of young (Table 27) produced to fledgling stage (BY) multiplied by 0lendorff's (1974) coefficient (OC) which provides the number of grams of food needed to produce 1 gram of hawk to fledgling stage plus the average number of days a young Swainson's hawk stays on the Hanford Site before migrating south (D) multiplied by the number of young present ( $Y$ ) multiplied by the food consumption ratio (QF) of Swainson's hawks (Johnson 1978). Assuming that the number of days between fledging and migration is 29 days (Fitzner 1980), then the following total young food consumption calculations result:

$$
(B Y \times O C)+(D \times Y \times Q F)
$$

$$
\begin{aligned}
& \text { TYFC } 1975=(23712 \times 5.7)+(29 \times 24 \times 100 \mathrm{~g} / \text { day })=205 \mathrm{~kg} \cdot \\
& \text { TYFC } 1976=(23712 \times 5.7)+(29 \times 24 \times 100 \mathrm{~g} / \text { day })=205 \mathrm{~kg} \cdot \\
& \text { TYFC } 1977=(16796 \times 5.7)+(29 \times 22 \times 100 \mathrm{~g} / \text { day })=145 \mathrm{~kg} . \\
& \text { TYFC } 1978=(21736 \times 5.7)+(29 \times 22 \times 100 \mathrm{~g} / \text { day })=188 \mathrm{~kg} .
\end{aligned}
$$

The total amount of food consumed by both adults and young for each year was:

$1975=695 \mathrm{~kg}, 1976=653 \mathrm{~kg}, 1977=565 \mathrm{~kg}$, and $1978=706 \mathrm{~kg}$. The mean for al1 four years was $655 \mathrm{~kg}$. When presented as food consumption per unit area, the Swainson's hawks consume $0.44 \mathrm{~kg} / \mathrm{km}^{2}\left(1.15 \mathrm{~kg} / \mathrm{km}^{2}\right)$ of food each year from the Hanford Site. This represents a minimum value, since young not reaching the fledging stage were not used in the computation of consumption rate. 


\section{HABITAT SELECTION}

The Hanford Site consists of the major shrub-steppe vegetation types shown in Figure 2. These are the sagebrush-bitterbrush/cheatgrass community, the sagebrush/bluebunch wheatgrass community and the sagebrush/cheatgrass community (Cline et al. 1977). Other minor plant associations with limited distribution on the Hanford Site include the winterfat (Ceratoides lanata) community; ridgecrest, containing a variety of low growing plants characterized by Poa sandbergii, Eriogonum thymoides, and Balsamorhiza rosea; riparian communities containing willows (salix sp.), Prunus sp., Amelanchier sp., Philadelphis sp., Rhus sp., and Rosa sp.; and island communities consisting of Lupinus sp., Eriogonum compositum, Achillea millifolium, Artemisia absynthium, and perennial grasses.

A few introduced trees planted for shade about farmsteads and military buildings are still alive and these trees are mostly Chinese elm (Ulmus sibericus), black locust (Robinia pseudoacacia), lombardy poplar (PopuTus sp.) and white poplar (Populus albus). Abandoned orchards are scattered throughout the area between old Hanford Townsite and 100-D area along the banks of the Columbia River.

Geological and engineered features occur throughout the Hanford Site. Cliff faces occur on Gable Mountain, White Bluffs, Rattlesnake hills, and Umtanum ridge. Transmission towers, water towers, meterological towers and buildings (pump houses, reactor buildings, deserted farmhouses) are scattered throughout the Site.

Major vegetation types and introduced trees and orchards are shown in Figure 2. Figures 7, 11 and 12 provide the locations of the owl and hawk nests observed in 1978. Geological features of the Hanford Site are shown in Figure 1. In grouping all raptors, a $78 \%$ utilization (78\% of observed nests were in this habitat) of the sagebrush/cheatgrass plant association is evident (Table 28). The sagebrush-bitterbrush/cheatgrass received the next highest use (10\%) while sagebrush/bluebunch wheatgrass and native riparian received six percent utilization. Table 28 provides a breakdown by species and plant associations. At first glance, one would believe that some species clearly have a preference for certain habitats. The long-eared owl, burrowing owl, marsh hawk and Swainson's hawk seem more adaptable than the other breeding raptor species in their use of tree plant associations while the barn owl, short-eared owl and prairie falcon seem to be the least adaptable in their use of one plant association. However, examination of the plant association use is quite misleading and any assumptions based on it are probably going to be inaccurate. Raptors, in general, probably occur where they do not so much as a result of the species composition of a plant community but because of prey species abundance and presence of adequate nest sites. Table 29 shows kinds of structures used for nesting as preferred by species. If we examine several species of raptors only on the basis of nest structure used, we will notice that they nested in the plant associations which contained suitable nest sites. Great horned owls nested only where 
TABLE 28. Differential Utilization (a) of Plant Associations by Nesting Birds of Prey on the Hanford Site-1978. (Percent utilization)

\begin{tabular}{|c|c|c|c|c|}
\hline & $\begin{array}{l}\text { Sagebrush-Bitterbrush/ } \\
\text { Cheatgrass }\end{array}$ & $\begin{array}{c}\text { Sagebrush/Bluebunch } \\
\text { Wheatgrass }\end{array}$ & $\begin{array}{l}\text { Sagebrush/ } \\
\text { Cheatgrass }\end{array}$ & $\begin{array}{l}\text { Native } \\
\text { Riparian }\end{array}$ \\
\hline $\begin{array}{l}\text { Great Horned ow } 1 \\
\text { Long-eared owl } \\
\text { Short-eared ow } 1 \\
\text { Barn owl } \\
\text { Burrowing ow } 1 \\
\text { Marsh hawk } \\
\text { Red-tailed hawk } \\
\text { Swainson's hawk } \\
\text { Prairie falcon } \\
\text { American kestrel }\end{array}$ & $\begin{array}{l}14 \%(1) \\
24 \%(5) \\
5 \%(1) \\
26 \%(5)\end{array}$ & $\begin{array}{c}10 \%(2) \\
17 \%(2) \\
5 \%(1) \\
7 \%(2) \\
\end{array}$ & $\begin{array}{c}71 \%(5) \\
43 \%(3) \\
100 \%(2) \\
100 \%(2) \\
66 \%(14) \\
58 \%(7) \\
95 \%(21) \\
69 \%(13) \\
100 \%(3) \\
93 \%(28) \\
\end{array}$ & $\begin{array}{l}29 \%(2) \\
43 \%(3)\end{array}$ \\
\hline Total Use & $10 \%$ & $6 \%$ & $78 \%$ & $6 \%$ \\
\hline
\end{tabular}

(a) Utilization means the number of nesting pairs or percent of nesting pairs observed in each habitat.

TABLE 29. Differential Utilization (a) of Nesting Structure by Birds of Prey on the Hanford Site--1978. (percent utilization)

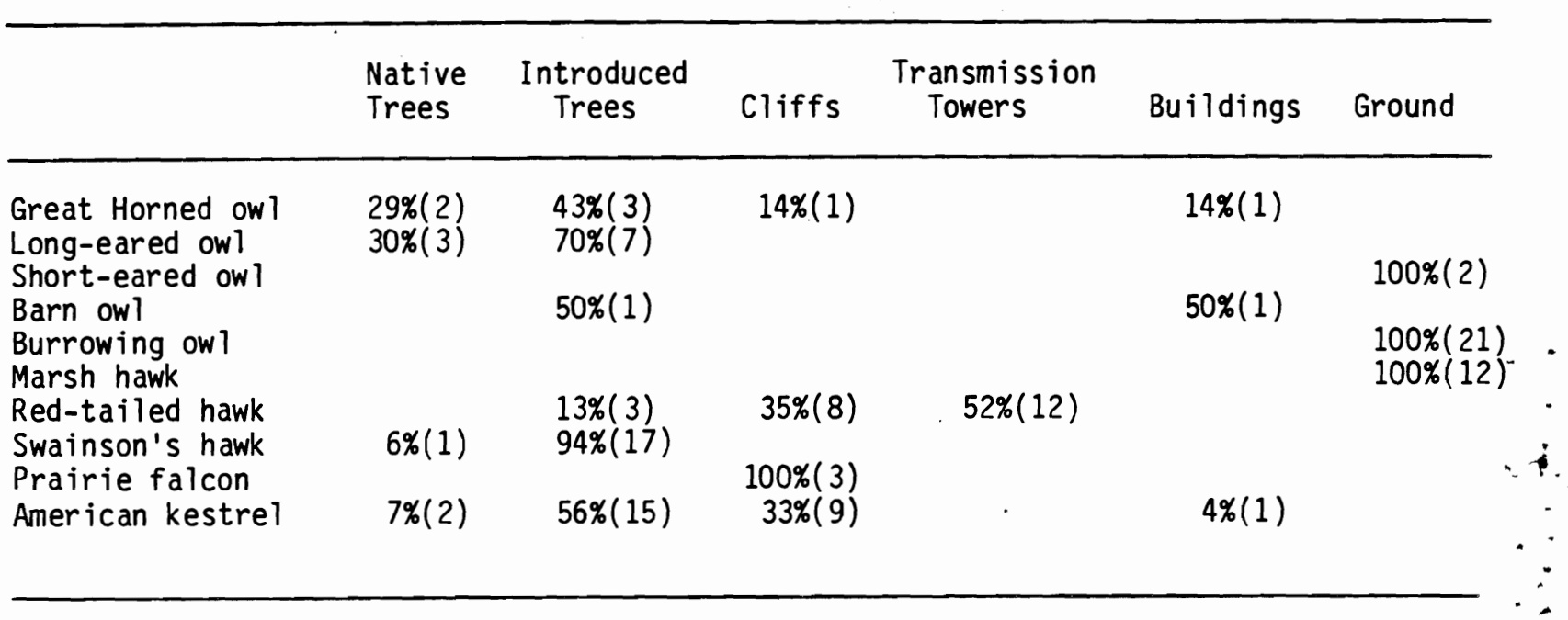

(a) Utilization means the number of nesting pairs or percent of nesting pairs observed in each habitat. 
trees, cliffs or buildings occured. Long-eared owls nested only in trees, short-eared owls nested on the ground, barn owls nested in trees and buildings, and burrowing owls nested on the ground. Red-tailed hawks often nested in transmission towers, on cliffs and in trees. Their distribution likely was controlled by nesting structure, not plant associates. Prairie falcons appear quite limited in their selection of plant associations used for nesting simply because they only nest on cliffs and cliffs only occurred in sagebrush/cheatgrass habitat. During the course of field work, we did notice a close association of several species with particular plant associations; however, this was probably a result of the availability of a suitable nesting structure or substrate. Long-eared and great horned owls, for instance, often nested in riparian areas. These areas contained trees of short stature, unsuitable for supporting the large bulky nest of a buteo, but were able to support some magpie nests which served as nest sites for long-eared and great-horned owls. Short-eared owls only nested in areas with dense cheatgrass vegetation. Cold Creek Valley near Benson Ranch on the ALE Reserve provided the proper vegetation structure for them. Marsh hawks also nested where dense ground vegetation occurred but utilized a wider range of densities in ground cover. 


\section{USE OF RAPTOR CASTINGS IN RADIOECOLOGICAL SURVEILLANCE}

Raptors regurgitate undigestible portions of their prey and cast pellets at their nesting and roosting areas. These have been collected and analyzed to study food habits for many years. They have recently been analyzed for radiocontaminants. Pellets were analyzed by initial gamma scan for radionuclides which might be released in the nuclear fuel cycle. The pellets analyzed in this study included 36 samples collected within the confines of the Hanford Site, four samples collected from a nearby offsite location near Ringold, and two samples collected from a distant offsite location in eastern Washington near Pullman (Figure 3). Twenty-five of the 36 onsite samples contained detectable levels of $137 \mathrm{Cs}$ (Table 30 ). Three of the four nearby offsite samples also had detectable levels of ${ }^{137} \mathrm{Cs}$, but the two distant offsite samples did not.

The ${ }^{137} \mathrm{Cs}$ content in raptor pellets ranged from about $0.1 \mathrm{pCi} / \mathrm{g}$ to $9.1 \mathrm{pCi} / \mathrm{g}$. Swainson's hawk pellets obtained from near the 200-E area had the single highest ${ }^{3} 37 \mathrm{Cs}$ concentration $(9.1 \mathrm{pCi} / \mathrm{g})$, while barn owl pellets obtained from the $100-D$ reactor area had the highest average ${ }^{137} \mathrm{Cs}$ concentration at $3.1 \mathrm{pCi} / \mathrm{g} \quad(n=5)$. Great horned ow 1 pellets from the $100-\mathrm{H}$ and $200-W$ areas had the next highest concentrations at about $1.4 \mathrm{pCi} / \mathrm{g}$. All other onsite samples with measurable ${ }^{137} \mathrm{Cs}$ contained less than $1 \mathrm{pCi} / \mathrm{g}$. The average for three barn ow 1 samples with detectable ${ }^{137} \mathrm{Cs}$ from the near offsite location was approximately $0.4 \mathrm{pCi} / \mathrm{g}$.

The initial gamma scan analyses indicated that at least one onsite sample contained gamma energies other than those included in the spectral stripping procedure used. Therefore, three of the onsite samples and two offsite samples were reanalyzed for gamma-emitting radionuclides using more sensitive multidimensional and anticoincident counting techniques (Cooper and Perkins 1972).

Results of the second analyses reaffirmed the validity of data for ${ }^{137} \mathrm{Cs}$ provided by the initial gamma scan. Several other radionuclides were identified from the samples (Table 31 ). Three primordial radionuclides $40_{\mathrm{K}}, 226_{\mathrm{Ra}}$ and $232 \mathrm{Th}\left(226 \mathrm{Ra}\right.$ detected by $214_{\mathrm{Bi}}$ gamma and $232 \mathrm{Th}$ detected by $208 \mathrm{~T} 1$ gamma) were also observed in samples from both onsite and offsite locations. The onsite sample that was suspected of containing gamma-emitting radionuclides not identified by the initjal gamma scan, a barn owl sample from 100-D area, contained $54 \mathrm{Mn}, 60 \mathrm{Co}, 152 \mathrm{Eu}, 154 \mathrm{Eu}$ and $155 \mathrm{Eu}$ in addition to $137 \mathrm{Cs}$ and the naturally occurring radionuclides. A great horned owl pellet sample from i the $100-\mathrm{H}$ area contained the same radionuclides except for $154 \mathrm{Eu}$, but in lower concentrations. The Swainson's hawk pellets having the highest ${ }^{137} \mathrm{Cs}$ concentration did not contain measurable ${ }^{54} \mathrm{Mn}, 60 \mathrm{Co}$ or any of the europium radionuclides.

Much of the ${ }^{137} \mathrm{Cs}$ associated with the raptor pellets is likely a result of global fallout originating from worldwide nuclear weapons testing. The data obtained for offsite samples are limited but the lower range of concentrations, 0.1 to $0.4 \mathrm{pCi} / \mathrm{g}$, may be attributed to fallout. Fallout ${ }^{137} \mathrm{Cs}$ 
TABLE 30. 137 Cs Concentrations in Raptor Pellet Samples

\begin{tabular}{|c|c|c|c|c|c|}
\hline \multirow[b]{2}{*}{ Location } & \multicolumn{5}{|c|}{ Species } \\
\hline & $\begin{array}{l}\text { Great } \\
\text { horned } \\
\text { ow } 7\end{array}$ & $\begin{array}{l}\text { Barn } \\
\text { ow } 1\end{array}$ & $\begin{array}{l}\text { Long- } \\
\text { eared } \\
\text { ow } 1\end{array}$ & $\begin{array}{l}\text { Red-tailed } \\
\text { hawk }\end{array}$ & $\begin{array}{c}\text { Swainson's } \\
\text { hawk }\end{array}$ \\
\hline & $\cdots-\cdots$ & $\cdots \cdots$ & $\mathrm{pCi} / \mathrm{g}$ dry wt & ------ & $-\cdots-\cdots$ \\
\hline \multicolumn{6}{|l|}{ Onsite } \\
\hline 100-D Area & & $\begin{array}{l}0.91 \pm 0.19 \\
5.9 \pm 2.9^{\mathrm{a}} \\
4.4 \pm 2.0 \\
0.37 \pm 0.09 \\
3.9 \pm 1.7\end{array}$ & & & $b$ \\
\hline $100-F$ Area & $\begin{array}{l}0.75+0.18 \\
0.64+0.26\end{array}$ & & b & & $b$ \\
\hline 100-H Area & $\begin{array}{l}1.50 \pm 0.16^{\mathrm{a}} \\
1.38 \pm 0.13 \\
1.37 \pm 0.15\end{array}$ & & & & \\
\hline 200-W Area & $1.24 \pm 0.37$ & & & & \\
\hline $200-E$ Area & & & $\begin{array}{l}0.79 \pm 0.21 \\
0.64 \pm 0.19 \\
0.57 \pm 0.07 \\
0.44 \pm 0.06\end{array}$ & & $9.10 \pm 0.37 a$ \\
\hline $\begin{array}{l}\text { Army Loop } \\
\text { Road }\end{array}$ & & & $0.37+0.18$ & & $\begin{array}{c}0.23 \pm 0.05 \\
0.18 \pm 0.05 \\
\frac{b}{b}\end{array}$ \\
\hline Gable Butte & $b$ & & & $b$ & \\
\hline $\begin{array}{l}\text { Hanford } \\
\text { Towns ite }\end{array}$ & $b$ & & & $0.78 \pm 0.37$ & \\
\hline $\begin{array}{l}\text { Rattlesnake } \\
\text { Springs }\end{array}$ & & & $\begin{array}{c}0.94+0.33 \\
\frac{b}{b}\end{array}$ & & \\
\hline Snively & $0.93 \pm 0.44$ & & & & \\
\hline 300 Area & & & & & $\begin{array}{l}0.14 \pm 0.04 \\
0.13 \pm 0.04\end{array}$ \\
\hline Offsite & & & & & \\
\hline Ringold & & $\begin{array}{l}0.41 \pm 0.13 \\
0.28 \pm 0.11 \\
0.43 \pm 0.14 \mathrm{a}\end{array}$ & & & $b$ \\
\hline Pullman & & & & & $\begin{array}{l}b^{a} \\
b\end{array}$ \\
\hline
\end{tabular}


TABLE 31. Radionuclide Concentrations Detected in Selected Samples by High Resolution Gamma Spectrometry

\begin{tabular}{|c|c|c|c|c|c|c|c|c|c|c|}
\hline \multirow{2}{*}{$\begin{array}{c}\text { Sample } \\
\text { Identification }\end{array}$} & \multicolumn{10}{|c|}{ Radionuclide } \\
\hline & ${ }^{137} \mathrm{Cs}$ & ${ }^{60} \mathrm{Co}$ & ${ }^{232} \mathrm{Th}^{\mathrm{a}}$ & ${ }^{22} \mathrm{Na}$ & $54 \mathrm{Mn}$ & $40_{K}$ & ${ }^{155_{E u}}$ & ${ }^{154} \mathrm{EU}$ & ${ }^{152} \mathrm{Eu}$ & ${ }^{226} \mathrm{Ra}^{\mathrm{b}}$ \\
\hline Onsite & -- & --- & -- & -- & $-p C i /$ & gdry & wt- - & -- & -- & $-\cdots$ \\
\hline $\begin{array}{l}\text { Barn ow } 1(100-D) \\
\text { Great horned }\end{array}$ & 6.04 & 9.0 & 0.15 & c & 5.6 & c & 2.02 & 10.1 & 64.9 & C \\
\hline $\begin{array}{l}\text { Owl } 1(100-H) \\
\text { Swainson's } \\
\text { hawk (200-E) }\end{array}$ & 13.5 & 0.41 & 0.09 & c & 0.19 & 2.69 & 0.18 & c & 0.38 & 0.21 \\
\hline Offsite & & & & & & & & & & \\
\hline $\begin{array}{l}\text { Barn ow } 1 \\
\text { (Ringold) } \\
\text { Swainson's } \\
\text { hawk(Pullman) }\end{array}$ & c & c & 0.05 & 0.01 & $c$ & 1.88 & 00 & 00 & 00 & 0.14 \\
\hline
\end{tabular}

a Detected as $214 \mathrm{Bi}$.

b Detected as 208T1.

c Less than detectable.

concentrations for raptor pel lets have not been documented in the literature, but Corley (1972) reported $137 \mathrm{Cs}$ and other radionuclides in great-horned owl pellets obtained from near the $100-\mathrm{H}$ area (Table 32).

The concentrations of $137 \mathrm{Cs}$ greater than $0.4 \mathrm{pCi} / \mathrm{g}$ and the presence of $60 \mathrm{Co}, 54 \mathrm{Mn}$, $152 \mathrm{Eu}, 154 \mathrm{Eu}$ and $155 \mathrm{Eu}$ in the onsite samples indicate that residual radionuclides remain in the environment from retired plutonium production facilities. The combination of radionuclides detected is similar to that reported by Corley (1972) except that his data showed the presence of several radionuclides that are either not detectable by gamma spectrometry or have such a short half-life that they could have decayed to below detection levels in our samples.

Resident raptors, by hunting over a territory of given size and depositing the undigested remains of their prey as pellets at roost or nest sites provide a practical way to detect radiocontaminants in raptor foods. These data suggest that different mixtures and concentrations of radionuclides can be detected in the regurgitated pellets of raptors occupying different areas (Tables 30 and 31). A practical application for the use of raptor castings is suggested in ecological monitoring programs since a single roost or nest site can provide an integrated sample that has been obtained by the bird in foraging over its territory. Analys is of raptor pellets can provide an indication of food chain transfers of radionuclides from waste disposal sites, reactors, and nuclear fuel processing facilities. An advantage of this method is that it does not impose mortality on the raptor population while it provides a continuous source of samples. 
TABLE 32. Radionuclide Concentrations in OWl Peliets (from Corley 1972, $\mu \mathrm{C} \mathrm{i} / \mathrm{g}$ )

\begin{tabular}{|c|c|c|}
\hline & Above $100-H$ & Near $100-F$ \\
\hline $\begin{array}{l}32 \mathrm{p} \\
54 \mathrm{Mn} \\
58 \mathrm{Co} \\
59 \mathrm{Fe} \\
60 \mathrm{Co} \\
90 \mathrm{Sr} \\
95 \mathrm{ZrNb} \\
106 \mathrm{Ru} \\
124 \mathrm{Sb} \\
137 \mathrm{Cs} \\
141 \mathrm{Ce} \\
144 \mathrm{Ce}-\mathrm{Pr} \\
154 \mathrm{Eu} \\
155 \mathrm{Eu} \\
233 \mathrm{~Pa} \\
239 \mathrm{Pu}\end{array}$ & $\begin{array}{l}\text { Not Significant } \\
10.2 \\
\text { Trace } \\
1.5 \pm 0.31 \\
25.5 \\
0.64 \\
4.5 \\
1.8 \pm 1.7 \\
0.45 \pm 0.26 \\
0.17 \pm 0.11 \\
0.30 \pm 0.29 \\
6.0 \pm 2.5 \\
\text { Trace } \\
\text { Trace } \\
\text { Trace } \\
0.0085\end{array}$ & $1.2 \times 10^{-5} \pm 9.2 \times 10^{-6}$ \\
\hline
\end{tabular}




\section{ACKNOWLEDGMENTS}

This study was supported in part by Rockwell Hanford Operations' Long-term Transuranic Defense Waste Program.

Additional support was provided by the Radioecology of Nuclear Fuel Cycles, Terrestrial Ecology and Long-Term Ecological Monitoring projects, funded by DOE's Office of Health and Environmental Research.

Appreciation is expressed to R. R. Olendorff, R. L. Knight, M. C. McShane, J. A. Warren, G. A. Bloomstrom, and J. N. Allen for their technical and field assistance. 


\section{REFERENCES}

Alcorn, G. D. 1971. Check 1ist - birds of the state of Washington. P. 414473 in Occasional paper No. 41, Dept. Biology, University of Puget Sound Press, Tacoma, Washington.

Brown, R. E. 1968. A study of reported faulting in the Pasco Basin. BNWL-662. Battelle, Pacific Northwest Laboratories, Richland, Washington. $47 \mathrm{pp}$.

Cline, J. F., D. W. Uresk, and W. H. Rickard. 1977. Plants and soil of a sagebrush community on the Hanford Reservation. Northwest Sci. 51:60-70.

Code of Federal Regulations. May 20, 1980. Title 50, Part 17.

Cooper, J. A., and R. W. Perkins. 1972. A versatile Ge-Li-NaI(TI) coincidence-anticoincidence gamma-ray spectrometer for environmental and biological problems. Nucl. Instrum. Methods 99:125-146.

Corley, J. P. 1972. Environmental Status of Hanford Reservation for 1970. BNWL-C-96. Battelle, Pacific Northwest Laboratories, Richland, Washington.

Craighead, F. C., and J. J. Craighead. 1956. Hawks, Owls, and Wildlife. Stockpole Co., Harrisburg, Pennsylvania.

Curtis, J. T., and R. P. McIntosh. 1950. The interrelations of certain analytical and synthetic phytosociological characters. Ecology 31:434-455.

Earhart, C. M., and N. K. Johnson. 1970. Size dimorphism and food habits of North American owls. Condor 72(3):251-264.

Enderson, J. H. 1964. Study of the prairie falcon in the central Rocky Mountain region. Auk $81: 332-352$.

Errington, P. 0. 1932. Technique of raptor food habits study. Condor $34: 75-86$.

Eyre, L., and D. Paul. 1973. Raptors of Utah. Publication No. 73-7. Utah Division of Wildlife Resources. $76 \mathrm{pp}$.

Fitzner, R. E., and J. N. Fitzner. 1975. Winter food habits of Short-Eared owls in the Palouse Prairie. Murrelet 56(2):2-4.

Fitzner, R. E., D. Berry, L. L. Boyd, and C. A. Rieck. 1977. Nesting of ferruginous hawks (Buteo regalis) in Washington, 1974-75. Condor

$79(2): 245-249$.

Fitzner, R. E. 1978. The Ecology and Behavior of Swainson's Hawk in Southeastern Washington. PhD Dissertation. Washington University Press, Pullman. 
Fitzner, R. E., and W. C. Hanson. 1979. Congregation of wintering bald eagles. Condor $81: 311-313$

Fitzner, R. E. 1980. Behavioral Ecology of the Swainson's Hawk in Southeastern Washington. PNL-2754. Pacific Northwest Laboratory, Richland, Washington.

Forsman, E., and C. Maser. 1970. Saw-whet ow1 preys on red tree mice. Murrelet $51(1): 10$.

Hanson, w. C. 1971. The 1966-67 snowy owl incursion in southeastern Washington and the Pacific northwest. Condor 73(1):114-116.

Hanson, W. C., and L. L. Eberhardt. 1970. A Columbia River Canada Goose Population. Wildlife Monograph No. 28. 61 p.

Hedlund, J. D. 1975. Tagging mule deer fawns in southcentral Washington. Northwest Sci. $49: 153-157$.

Howard, R. P., and M. L. Wolfe. 1976. Range improvement practices and ferruginous hawks. J. Range Manage. 29:33-37.

Hudson, G. E., and C. F. Yocom. 1954. A Distributional list of the Birds of southeastern Washington. Research studies of the State College of Washington, Vol. 22, No. 1, Pullman, Washington. $56 \mathrm{pp}$.

Jewett, S. G., W. P. Taylor, W. T. Shaw, and J. W. Aldrich. 1953. Birds of Washington state. University of Washington Press, Seattle, Washington. $767 \mathrm{pp}$.

Johnson, D. R. 1978. The Study of Raptor Populations. University Press of Id aho, Moscow.

Marti, C. D. 1974. Feeding and ecology of four sympatric owls. Condor $76(1): 45-61$.

Moon, E. L. 1949. Notes on hawk and owl pellet formation and identification. Trans. Kansas Acad. Sci. 43:458-466.

O'Farrell, T. P., R. J. Olsen, R. 0. Gilbert and J. D. Hedlund. 1975. A population of Great Basin pocket mice, Perognathus parvus, in the shrub-steppe of South-central Washington. Ecological Monographs 45(1):1-28.

Olendorff, R. R. 1971. Falconiform reproduction; a review. Pt. 1, the prenesting period. Raptor Research Rpt. No. 211. $233 \mathrm{pp}$.

0lendorff, R. R. 1973a. Raptorial birds of the U.S.A.E.C. Hanford Reservation, South-central Washington. BNWL-1790. Battelle, Pacific Northwest Laboratories, Richland, Washington. $45 \mathrm{pp}$. 
Olendorff, R. R. 1973b. Ecology of Nesting Birds of prey of North-eastern Colorado. U.S. IBP Grassiand Biome Tech. Rep. No. 211. Colorado State Univ., Fort Collins, CO.

Olendorff, R. R. 1974. Some quantitative aspects of growth in three species of buteos. Condor 76(4):466-468.

Rickard, W. H., J. D. Hedlund and R. G. Schreckhise. 1974. Mammals of the Hanford Reservation in Relation to Management of Radioactive Waste. BNWL-1877. Battelle, Pacific Northwest Laboratories, Richland, Washington. 58 pp.

Smith, D. G., and J. R. Murphy. 1973. Breeding ecology of raptors in the eastern Great Basin of Utah. Brigham Young University Sci. Bu11. Biol. Ser. 18(3):1-76. Provo, Utah.

Smith, D. G., and C. R. Wilson. 1971. Notes on the winter food of screech owls in central Utah. Great Basin Naturalist 31(2):83-84.

Springer, A. M. 1975. Observations on the summer diet of rough-legged hawks from Alaska. Condor 77(3):338-339.

Stone, W. A., D. E. Jenne, and J. M Thorp. 1972. Climatography of the Hanford Area. BNWL-1605. Battelle, Pacific Northwest Laboratories, Richland, Washington. $276 \mathrm{pp}$.

Thorp, J. M., and W. T. Hinds. 1977. Microclimates of the Arid Lands Ecology Reserve, 1968-1975. BNWL-SA-6231. Battel1e, Pacific Northwest Laboratories, Richland, Washington. $100 \mathrm{pp}$.

Thomsen, L. 1971. Behavior and ecology of burrowing owls on the 0akland municipal airport. Condor 73:177-192.

U.S. Department of Interior. 1973. The Channeled Scablands of Eastern Washington. No. 2401-02436. GPO. Washington, DC.

VanCamp, L. F., and C. J. Henny. 1975. The Screech Owl: Its life history and population ecology in northern Ohio. North American Fauna No. 71. Woodby, D. A. 1976. Winter owl records for eastern Washington. Murrelet $57: 16-17$. 


\section{DISTRIBUTION}

No. of

Copies

\section{OFFSITE}

A. A. Churm

DOE Chicago Patent Attorney

9800 South Cass Avenue

Argonne, IL 60439

27 DOE Technical Information Center

Department of Energy

Assistant Secretary for

Environment

Washington, DC 20545

P. B. Dunaway

DOE Nevada Operations

P.0. Box 14100

Las Vegas, NV 89114

0. D. Markham

Radiological and Environmental

Sciences Laboratory

DOE Idaho Operations Office

P.0. Box 2108

Idaho Falls, ID 83401

7 DOE Office of Health and Environmental Research
N. F. Barr
W. W. Burr
C. E. Carter
R. C. Dahlman
R. E. Franklin
W. S. Osburn
J. Swinebroad
R. L. Watters

No. of

Copies

\section{S. Meyers}

DOE Office of Nuclear Waste Management

Washington, DC 20545

S. I. Auerbach

Oak Ridge National

Laboratory

P.0. Box $X$

Oak Ridge, TN 37830

I. L. Brisbin, Jr.

Savannah River Ecology Laboratory

Aiken, SC 29801

Office of Nuclear Waste

$$
\text { Isolation }
$$

Att: Beverly Rawles

Battelle Memorial Institute

505 King Avenue

Columbus, $\mathrm{OH} 43201$

T. E. Hakonson

Los Alamos Scientific Laboratory

P.0. Box 1663

Los Alamos, NM 86544

M. Smith, Director

Savannah River Ecology Laboratory

Drawer E

Aiken, SC 29801

F. W. Whicker

Radiology and Radiation

Biology Department

Colorado State University

Fort Collins, CO 80521 
No. of

Copies

\section{ONSITE}

38

Pacific Northwest Laboratory

W. J. Bair

L. L. Cadwe 11

R. E. Fitzner

K. E. Harding

D. E. Olesen

W. H. Rickard

R. G. Schreckhise

W. L. Templeton

B. E. Vaughan

M. L. Warner

W. R. Wiley

Technical Information (5)

Publishing Coordination (2)

Hanford Engineering Development Laboratory

G. D. Carpenter

United Nuclear, Inc.

T. E. Dabrowski

10 DOE - Richland Operations

J. C. Cummings

0. J. Elgert/J. L. Rhoades

R. E. Gerton
No. of

Copies

DOE - Richland Operations (cont)

B. R. Goranson

H. E. Ransom/R. Austin

M. W. Shupe

F. R. Standerfer/P. G. Harris

M. W. Tiernan/D. R. Elle

M. G. White/P. F. Dunigan

M. J. Zamorski

\section{Rockwe 11 Hanford Operations}

D. J. Brown

L. E. Bruns

J. L. Deichman

R. D. Fox

M. K. Harmon

W. F. Heine

R. E. Isaacson

W. P. Kunke 1

D. S. Landeen

P. G. Lorenzini

C. W. Manry

H. E. McGuire

R. M. Mitchel1

W. L. Nees

D. Paine

J. H. Roecker

D. L. Uh 1

R. E. Wheeler

D. D. Wodrich 